\title{
Atmospheric inorganic nitrogen input via dry, wet, and sea fog deposition to the subarctic western North Pacific Ocean
}

\author{
J. Jung ${ }^{1,2}$, H. Furutani ${ }^{1}$, M. Uematsu ${ }^{1}$, S. Kim ${ }^{2}$, and S. Yoon ${ }^{2}$ \\ ${ }^{1}$ Atmosphere and Ocean Research Institute, The University of Tokyo, Kashiwa, Japan \\ ${ }^{2}$ School of Earth and Environmental Sciences, Seoul National University, Seoul, South Korea
}

Correspondence to: J. Jung (jinyoung_jung@snu.ac.kr)

Received: 2 July 2012 - Published in Atmos. Chem. Phys. Discuss.: 2 August 2012

Revised: 30 November 2012 - Accepted: 19 December 2012 - Published: 15 January 2013

\begin{abstract}
Aerosol, rainwater, and sea fog water samples were collected during the cruise conducted over the subarctic western North Pacific Ocean in the summer of 2008, in order to estimate dry, wet, and sea fog deposition fluxes of atmospheric inorganic nitrogen $(\mathrm{N})$. During sea fog events, mean number densities of particles with diameters larger than $0.5 \mu \mathrm{m}$ decreased by $12-78 \%$, suggesting that particles with diameters larger than $0.5 \mu \mathrm{m}$ could act preferentially as condensation nuclei $(\mathrm{CN})$ for sea fog droplets. Mean concentrations of nitrate $\left(\mathrm{NO}_{3}^{-}\right)$, methanesulfonic acid (MSA), and non sea-salt sulfate (nss- $\mathrm{SO}_{4}^{2-}$ ) in sea fog water were higher than those in rainwater, whereas those of ammonium $\left(\mathrm{NH}_{4}^{+}\right)$in both sea fog water and rainwater were similar. These results reveal that sea fog scavenged $\mathrm{NO}_{3}^{-}$and biogenic sulfur species more efficiently than rain. Mean dry, wet, and sea fog deposition fluxes for atmospheric total inorganic $\mathrm{N}$ (TIN; i.e. $\mathrm{NH}_{4}^{+}+\mathrm{NO}_{3}^{-}$) over the subarctic western North Pacific Ocean were estimated to be $4.9 \mu \mathrm{mol} \mathrm{m}{ }^{-2} \mathrm{~d}^{-1}$, $33 \mu \mathrm{mol} \mathrm{m}{ }^{-2} \mathrm{~d}^{-1}$, and $7.8 \mu \mathrm{mol} \mathrm{m} \mathrm{m}^{-2} \mathrm{~d}^{-1}$, respectively. While $\mathrm{NO}_{3}^{-}$was the dominant inorganic $\mathrm{N}$ species in dry and sea fog deposition, inorganic $\mathrm{N}$ supplied to surface waters by wet deposition was predominantly by $\mathrm{NH}_{4}^{+}$. The contribution of dry, wet, and sea fog deposition to total deposition flux for TIN (46 $\mu \mathrm{mol} \mathrm{m} \mathrm{m}^{-2} \mathrm{~d}^{-1}$ ) were $11 \%, 72 \%$, and $17 \%$, respectively, suggesting that ignoring sea fog deposition would lead to underestimate of the total influx of atmospheric inorganic $\mathrm{N}$ into the subarctic western North Pacific Ocean, especially in summer periods.
\end{abstract}

\section{Introduction}

Atmospheric transport of particulate matter from the continents to the oceans is well recognized as a major pathway for supply of natural and anthropogenic materials to open ocean surface waters, including nutrients (Duce et al., 1991; Jickells, 1995). Previous studies have highlighted the significance of the atmosphere as a pathway for transport of essential nutrients for biological growth such as nitrogen $(\mathrm{N})$, from continents to marine surface waters and its critical role in oceanic biogeochemical cycling (e.g. Duce et al., 1991, 2008; Prospero et al., 1996; Paerl, 1997; Galloway et al., 2004; Dentener et al., 2006; Baker et al., 2010; Kim et al., 2011; Jung et al., 2011).

While numerous studies have dealt with the input of nutrients via atmospheric deposition, especially dry and wet deposition, relatively little is known about the deposition flux of atmospheric constituents by fog (Lange et al., 2003). Scavenging processes of water-soluble gases (e.g. $\mathrm{HNO}_{3}, \mathrm{NH}_{3}$, and $\mathrm{SO}_{2}$ ) and aerosols in the atmosphere by fog events are determined by the properties of ionic compositions in fog water and by the growth rate of fog droplets during fog events (Aikawa et al., 2007). The chemical compositions of the particles acting as condensation nuclei $(\mathrm{CN})$ determine the initial compositions of the fog droplets, which can be further altered by uptake of water-soluble gases and by aqueous phase chemical reactions (Sasakawa et al., 2003; Raja et al., 2008). In fog, the condensation of water vapor on pre-existent particles in the boundary layer shifts the aerosol size distribution towards larger sizes and accelerates their removal from the atmosphere (Jacob et al., 1984; Sasakawa et al., 2003; Herckes et al., 2007; Li et al., 2011). The deposition of fog 
can contribute significantly to the hydrologic, pollutant, and nutrient cycles in coastal and mountainous regions, since it is an important transfer process for water and various inorganic and organic substances from the atmosphere to the biosphere (Lovett et al., 1982; Jacob et al., 1984; Collett et al., 2001; Zhang and Anastasio, 2001; Klemm and Wrzesinsky, 2007). However, quantifying fog deposition flux for atmospheric nutrient or pollutant and assessing its impact are still a challenge in atmospheric science and ecosystem research (Klemm and Wrzesinsky, 2007).

Considerable effort has been devoted to investigating the chemical and physical properties of fog in valleys, mountains, and urban areas (e.g. Collett et al., 2001; Burkard et al., 2002; Collett et al., 2002; Moore et al., 2004; Lu et al., 2010; Li et al., 2011). However, sea fog has not been extensively investigated (e.g. Sasakawa and Uematsu, 2002, 2005; Sasakawa et al., 2003); although it may stimulate phytoplankton growth over the oceanic regions where sea fog occurs frequently and atmospheric nutrients derived from natural and anthropogenic sources are transported and/or affected (Sasakawa et al., 2003). It is therefore necessary to clarify the scavenging process of atmospheric nutrients by sea fog and to quantify their deposition flux to the sea surface.

Rapid growth in human population and industrial activity have led to increases in the concentrations of reactive $\mathrm{N}$ species throughout the environment (Galloway et al., 2008). In particular, the increase in nitrogen oxides $\left(\mathrm{NO}_{\mathrm{x}}\right)$ emissions in eastern Asia has been dramatic over the last decade (Akimoto, 2003; Uno et al., 2007). The western North Pacific receives a large influx of mineral particles and pollutants from the Asian continent through atmospheric long-range transport (Uematsu et al., 1983, 2010; Gao et al., 1992; Nakamura et al., 2005). Accordingly, estimating deposition flux of atmospheric $\mathrm{N}$ and evaluating its impact on marine biogeochemical cycles over the western North Pacific have become increasingly important. In addition, the subarctic western North Pacific $\left(>40^{\circ} \mathrm{N}\right)$ has a high sea fog frequency, with a maximum of $\sim 50 \%$ during the summertime period from June to August (Wang, 1985). Nevertheless, no study has been carried out over this region to estimate atmospheric $\mathrm{N}$ input via dry, wet, and sea fog deposition simultaneously. This study therefore aims to (1) investigate general characteristics of sea fog, (2) estimate the fluxes of atmospheric $\mathrm{N}$ via dry, wet, and sea fog deposition, (3) estimate the contribution of each deposition to atmospheric $\mathrm{N}$ input, and (4) evaluate the impact of atmospheric $\mathrm{N}$ deposition on the ocean marine ecosystem. In this study, we focus on ammonium $\left(\mathrm{NH}_{4}^{+}\right)$and nitrate $\left(\mathrm{NO}_{3}^{-}\right)$that are dominant components for $\mathrm{N}$ supply to the oceans (Krishnamurthy et al., 2010). The results for atmospheric inorganic $\mathrm{N}$ deposition from this study should be valuable for filling the data gap, especially for the atmospheric inorganic $\mathrm{N}$ input by sea fog deposition to the subarctic western North Pacific Ocean.

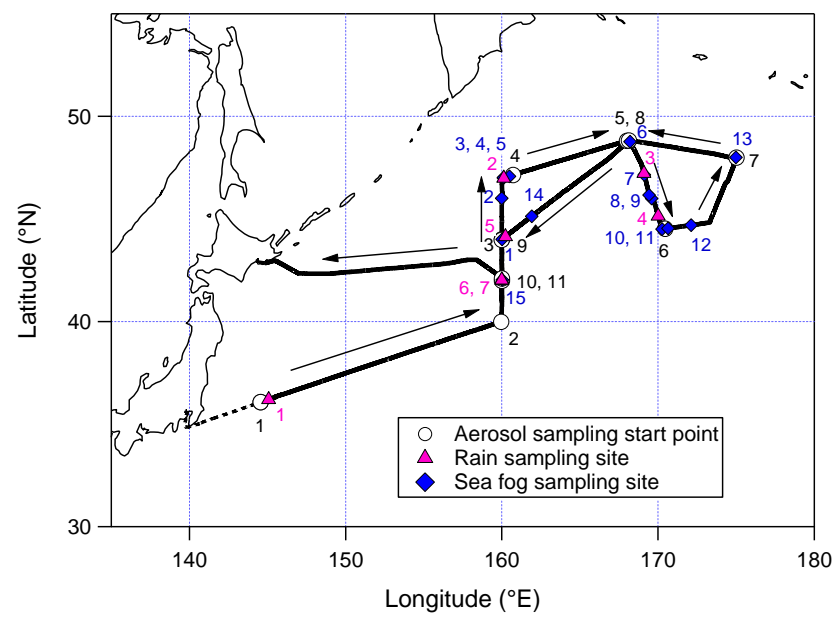

Fig. 1. Cruise track of Leg 1 of the KH-08-2. White circles, pink triangles, and blue diamonds indicate aerosol, rain, and sea fog sampling locations during the cruise, respectively. Each aerosol sampling start point represents the end of the previous sampling period. Dotted line indicates that no aerosol sampling was conducted. Black, pink, and blue numbers represent the sample numbers of aerosol, rain, and sea fog, respectively.

\section{Methods}

Aerosol $(n=11)$, rain $(n=7)$, and sea fog $(n=15)$ samples were collected over the subarctic western North Pacific Ocean during Leg 1 of the KH-08-2 cruise (29 July-19 August 2008) aboard R/V Hakuho Maru (Fig. 1).

\subsection{Aerosol collection}

A high-volume virtual impactor air sampler (AS-9, Kimoto Electric Co., Ltd.) was used to collect marine aerosols on a Teflon filter (PF040, $90 \mathrm{~mm}$ in diameter, Advantec) (Nakamura et al., 2005; Jung et al., 2011). The virtual impactor air sampler utilizes an acceleration nozzle to divide the intake air into the major flow carrying the fine particles $(D<2.5 \mu \mathrm{m})$ and the minor flow carrying the coarse particles $(D>2.5 \mu \mathrm{m})$. The major air flow is diverted laterally after passing through the acceleration nozzle and the inertia of the coarse particles carries them into a collection probe aligned with the acceleration nozzle. Both particle fractions are then collected on the same filter. Details of the virtual impactor are described in Loo and Cork (1988). The aerosol sampler was put on the front of the upper deck ( $17 \mathrm{~m}$ a.s.l.) of the ship. A wind-sector controller was used to avoid contamination from the ship's exhaust during aerosol sampling. The windsector controller system was configured to allow collection of marine aerosol samples only when the relative wind directions were within plus or minus $100^{\circ}$ relative to the ship's bow and the relative wind speeds were over $1 \mathrm{~m} \mathrm{~s}^{-1}$ during the cruise. The flow rate was approximately $13 \mathrm{~m}^{3} \mathrm{~h}^{-1}$ and the total sampling time was $1-3$ days, representing a total 
sampling air volume of $310-930 \mathrm{~m}^{3}$. After sampling, the filter was stored frozen at $-24{ }^{\circ} \mathrm{C}$ prior to chemical analysis. Deployment blanks $(n=3)$ were obtained by placing Teflon filters in the aerosol sampler for $5 \mathrm{~min}$ on idle systems (i.e. no airflow through the filters) and processed as other aerosol samples.

During the KH-08-2 cruise, number densities of ambient particles in four size fractions of $D>0.3,0.5,1.0$, and $2.0 \mu \mathrm{m}$ were also measured continuously using an optical particle counter (KC-01D, Rion Co., Inc). Meteorological variables (i.e. wind speed, wind direction, air temperature, sea temperature, dew point, and relative humidity) were continuously monitored by weather monitoring systems equipped on the research vessel.

\subsection{Rainwater collection}

Rainwater sampling was conducted on an event basis during the cruise. Rain samples were collected with a $36.5 \mathrm{~cm}$ diameter polyethylene funnel fitted to a $500 \mathrm{ml}$ polyethylene bottle (Jung et al., 2011). Both the funnel and bottle were first soaked in detergent (Contaminon B, Wako Pure Chemical Industries) for $24 \mathrm{~h}$, then soaked in $1 \mathrm{~N} \mathrm{HCl}$ for $24 \mathrm{~h}$, before being rinsed at least three times with Milli-Q water ( $>18 \mathrm{M} \Omega \mathrm{cm}^{-1}$; Millipore Co.) and finally dried in a drying oven (DK 600, Yamato, Japan) prior to deployment. The rain sampler was put on the front of the upper deck of the ship, and was opened manually just before or as soon as possible after precipitation. During rain collection, the relative wind directions were monitored. If rain occurred when the relative wind directions were outside the ranges of the wind-sector controller, the rainwater was not collected. After collection, the rain sampler was washed thoroughly with Milli-Q water and closed. The rainwater samples were immediately separated into three aliquots. Two of the aliquots were used for measurements of $\mathrm{pH}$ (Model 290A, Orion) and conductivity (Model 115, Orion), respectively. When the amount of precipitation was less than $10 \mathrm{ml}, \mathrm{pH}$ and conductivity were not measured. The $\mathrm{pH}$ and conductivity meters were calibrated before each measurement. Standard pH 4.01 and 7.00 buffer (Thermo Scientific) and conductivity/total dissolved solids (TDS) standard ( $1413 \mu \mathrm{S} \mathrm{cm}^{-1}$, Thermo Scientific) solutions were used for calibrations of the $\mathrm{pH}$ and conductivity meters, respectively. As the third aliquot, remaining rainwater was sealed in pre-cleaned $100 \mathrm{ml}$ high-density polyethylene (HDPE) bottles, and stored in a freezer at $-24^{\circ} \mathrm{C}$ prior to chemical analyses. Procedural blanks $(n=3)$ for rainwater were collected by pouring $100 \mathrm{ml}$ of Milli-Q water through the clean funnel-bottle assembly. The procedural blanks were also treated as other rainwater samples.

\subsection{Sea fog water collection}

Sea fog water sampling was conducted on an event basis during the cruise. A fog water sampler (FWG-400, Usui Co.
Inc.) was used to collect sea fog water and put on the front of the upper deck of the ship. The fog water sampler is composed of a net of Teflon strings $(0.5 \mathrm{~mm}$ in diameter), a net holder and a $500 \mathrm{ml}$ low-density polyethylene (LDPE) bottle. Prior to deployment, both the net and the bottle were first soaked in the detergent for $24 \mathrm{~h}$, then soaked in a $1 \mathrm{~N} \mathrm{HCl}$ for $24 \mathrm{~h}$, then rinsed at least three times with Milli-Q water and finally dried. The net of Teflon strings and the LDPE bottle were set only during the sea fog occurrence and removed once sea fog event ceased. When the ship sails the sea fog occurrence area, sea fog droplets collide with the strings and drop along the strings into the $500 \mathrm{ml}$ LDPE bottle beneath the strings (Sasakawa et al., 2003). Likewise rain sampling, the relative wind directions were monitored during sea fog water collection, and sea fog water samples were collected only when the relative wind directions were within the ranges of the wind-sector controller. If the relative wind directions changed from within to outside the ranges during sea fog water sampling, the sea fog water was considered contaminated and discarded. After collection, sea fog water samples were immediately separated into three aliquots. Two of the aliquots were used for measurements of $\mathrm{pH}$ and conductivity, respectively. The third aliquot was sealed in pre-cleaned $100 \mathrm{ml}$ HDPE bottles, and stored in a freezer at $-24^{\circ} \mathrm{C}$ prior to chemical analyses. Procedural blanks $(n=5)$ for sea fog water samples were collected by pouring $100 \mathrm{ml}$ of Milli-Q water through the clean net-bottle assembly. The procedural blanks were also treated as sea fog water samples.

Size distributions of sea fog droplets were measured with a fog monitor (FM-100, Droplet Measurement Technologies). The fog monitor detects the number and size of individual fog droplets with a diameter from roughly $2 \mu \mathrm{m}$ up to $50 \mu \mathrm{m}$ by the forward scattering principle, and can classify droplets in up to 40 size classes (Klemm et al., 2005). Liquid water content (LWC) for each of the 40 droplet size classes was computed based on an idealized mean volume of spherical droplets with aerodynamic diameter. Total LWC was obtained from the sum of LWC for all size. Until now, the uncertainties of droplet measurements for the fog monitor have not been considered in most studies. Recently, Spiegel et al. (2012) evaluated the influence of Mie scattering on the droplet size spectra collected with the fog monitor and the droplet losses during sampling with the fog monitor. They also recommended choosing the 40 channel thresholds to reduce the error from Mie scattering, and doing loss calculations for the droplet measurements using an ultrasonic anemometer and other instrument (e.g. Particulate Volume Monitor) for a reference. In this study, the 40 channel thresholds were used for the measurement of sea fog droplets, indicating that it is sufficient for the determination of the total droplet number concentration or the total liquid water content (Spiegel et al., 2012). However, the droplet losses during sampling with the fog monitor were not calculated since an ultrasonic anemometer and other instrument for a reference were not used in this study. 


\subsection{Chemical analysis}

Aerosol, rainwater, and sea fog water samples were analyzed for major ionic and inorganic $\mathrm{N}$ species $\left(\mathrm{NH}_{4}^{+}\right.$and $\left.\mathrm{NO}_{3}^{-}\right)$ using the method described in detail elsewhere (Jung et al., 2011). Briefly, aerosol samples were ultrasonically extracted using $50 \mathrm{ml}$ of Milli-Q water. The extraction solution was then filtered, as were the rainwater and sea fog water samples, through a $13-\mathrm{mm}$ diameter, $0.45-\mu \mathrm{m}$ pore-size membrane filter (PTFE syringe filter, Millipore Co.). The filtrates of aerosol extracts, rainwater, and sea fog water samples were analyzed by ion chromatography (IC; Dionex-320, Thermo Scientific Dionex) for anions $\left(\mathrm{Cl}^{-}, \mathrm{MSA}, \mathrm{NO}_{3}^{-}\right.$, and $\left.\mathrm{SO}_{4}^{2-}\right)$ and cations $\left(\mathrm{Na}^{+}, \mathrm{NH}_{4}^{+}, \mathrm{K}^{+}, \mathrm{Mg}^{2+}\right.$, and $\left.\mathrm{Ca}^{2+}\right)$. The instrumental detection limits were: $\mathrm{Cl}^{-} 0.035 \mu \mathrm{M}$, MSA $0.031 \mu \mathrm{M}$, $\mathrm{NO}_{3}^{-} 0.1 \mu \mathrm{M}, \mathrm{SO}_{4}^{2-} 0.065 \mu \mathrm{M}, \mathrm{Na}^{+} 0.11 \mu \mathrm{M}, \mathrm{NH}_{4}^{+} 0.17 \mu \mathrm{M}$, $\mathrm{K}^{+} 0.16 \mu \mathrm{M}, \mathrm{Mg}^{2+} 0.15 \mu \mathrm{M}$, and $\mathrm{Ca}^{2+} 0.16 \mu \mathrm{M}$.

Non sea-salt (nss-) concentrations of some ionic components were calculated by subtracting the component's seasalt-derived (ss-) concentration from its total concentration. In this study, it was assumed that all $\mathrm{Na}^{+}$in aerosols, rainwater and sea fog water were derived from sea-salt. Contributions from sea-salt were calculated from the $\mathrm{Na}^{+}$concentration in aerosols, rainwater or sea fog water using the mole ratio of the component of interest to $\mathrm{Na}^{+}$in seawater (Keene et al., 1986).

\subsection{Backward trajectory analysis}

Air mass backward trajectories (AMBTs) provide a better understanding of air flow and long-range transport of aerosols. In particular, AMBTs have been used to identify the origin of primary aerosols collected far away from their source region (Chiapello et al., 1997). In this study, 7-day AMBTs were calculated from the National Oceanic and Atmospheric Administration (NOAA) GDAS (Global Data Assimilation System) database using the Hybrid Single-Particle Lagrangian Integrated Trajectories (HYSPLIT) model (NOAA Air Resources Laboratory, http:// www.arl.noaa.gov/ready/hysplit4.html). AMBTs were performed at 500, 1000, and $1500 \mathrm{~m}$ above ground level. Chen and Siefert (2004) reported that atmospheric aerosols may not follow the resulting trajectories because of scavenging processes and gravitational settling; however, the AMBTs provide useful background data on airstreams and the potential origins of the source of the sampled air mass.

\subsection{Deposition flux estimates}

\subsubsection{Dry deposition}

Dry deposition fluxes $\left(F_{\mathrm{d}}\right)$ were calculated from aerosol concentrations $\left(C_{\mathrm{a}}\right)$ in the coarse (c) and fine (f) modes and dry deposition velocities $\left(V_{\mathrm{d}}\right)$ for each size mode (Duce et al.,
1991; Baker et al., 2007):

$F_{\mathrm{d}}=C_{\mathrm{a}}^{\mathrm{c}} V_{\mathrm{d}}^{\mathrm{c}}+C_{\mathrm{a}}^{\mathrm{f}} V_{\mathrm{d}}^{\mathrm{f}}$

Here, dry deposition velocities of $2 \mathrm{~cm} \mathrm{~s}^{-1}$ for coarse mode and $0.1 \mathrm{~cm} \mathrm{~s}^{-1}$ for fine mode were used since these two values are known to be best estimates based on experimental and model studies (e.g. Duce et al., 1991; Baker et al., 2003; Nakamura et al., 2005). This estimate results in an uncertainty of a factor of 2-3 in the calculated flux, since deposition velocity includes terms for gravitational settling, impaction and diffusion of particles, all of which vary in complex functions of particle size and meteorological conditions (e.g. wind speed and relative humidity) (Duce et al., 1991)

\subsubsection{Wet deposition}

Wet deposition fluxes $\left(F_{\mathrm{w}}\right)$ were estimated from the concentration of the species of interest in rainwater $\left(C_{\mathrm{r}}\right)$ and the precipitation rate $(P)$ (Baker et al., 2010):

$F_{\mathrm{w}}=C_{\mathrm{r}} P$

The precipitation rate was calculated from the monthly averaged precipitation rate $\left(\mathrm{mm} \mathrm{d}^{-1}\right)$ using the CMAP model output (http://www.cdc.noaa.gov/cdc/data.cmap.html) (Xie and Arkin 1997). Similar to estimates for dry deposition flux, the choice of precipitation rates based on limited data causes the greatest uncertainty in wet deposition flux estimates, particularly in the open ocean (Spokes et al., 2000). However, Baker et al. (2010 and references therein), who used the same method for estimating wet deposition flux, argued that the uncertainty arising from selection of precipitation rate is minor since the precipitation rate data agreed relatively well with other studies in terms of total rainfall amount.

\subsubsection{Sea fog deposition}

Sea fog deposition fluxes $\left(\mathrm{F}_{\mathrm{f}}\right)$ were estimated by multiplying sea fog water flux $\left(F_{\mathrm{fw}}\right)$ of each event by the concentration of the species of interest in each sea fog water sample $\left(\mathrm{C}_{f}\right)$ (Thalmann et al., 2002):

$F_{\mathrm{f}}=F_{\mathrm{fw}} \times C_{\mathrm{f}}$

The $F_{\mathrm{fw}}$ was estimated by Eq. (4), where $\mathrm{LWC}\left(\mathrm{D}_{\mathrm{p}}\right)$ represents the mean LWC for each of the 40 droplet size classes during each sea fog event and $V\left(D_{\mathrm{p}}\right)$ indicates the deposition velocity for sea fog droplets with an aerodynamic diameter (Klemm et al., 2005). The sum of sea fog water flux for all size classes then yielded the $F_{\mathrm{fw}}$.

$F_{\mathrm{fw}}=\sum \operatorname{LWC}\left(D_{\mathrm{p}}\right) \times V\left(D_{\mathrm{p}}\right)$

For $\mathrm{V}\left(\mathrm{D}_{p}\right)$, the modeled values reported by Matsumoto et al. (2011), who calculated the deposition velocities for the particles with diameters larger than $3 \mu \mathrm{m}$, were 


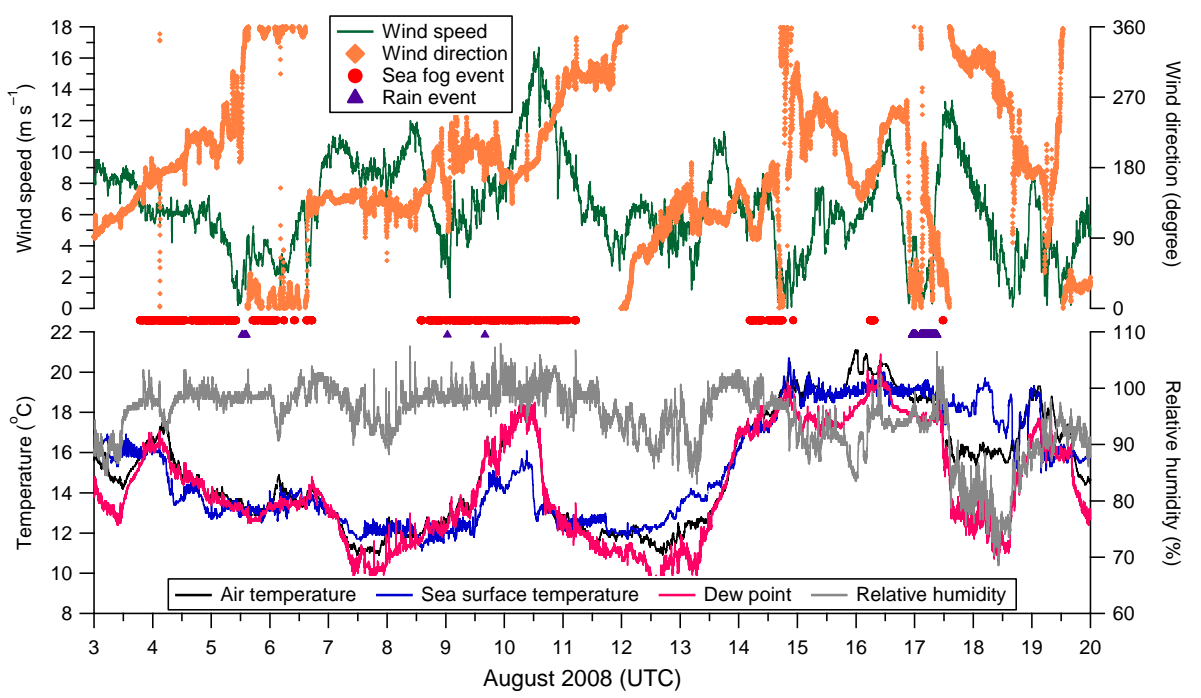

Fig. 2. Temporal variations of meteorological variables (i.e. wind speed, wind direction, air temperature, sea surface temperature, dew point, and relative humidity) during the cruise. Sea fog (red circle) and rain (violet triangle) events indicate the occurrences of observed sea fog and rain events, respectively.

used (i.e. $4.69 \mathrm{~cm} \mathrm{~s}^{-1}$ for $3<D<5 \mu \mathrm{m}, \quad 10.1 \mathrm{~cm} \mathrm{~s}^{-1}$ for $5<D<10 \mu \mathrm{m}, \quad 13.5 \mathrm{~cm} \mathrm{~s}^{-1}$ for $10<D<20 \mu \mathrm{m}$, $15.6 \mathrm{~cm} \mathrm{~s}^{-1}$ for $20<D<30 \mu \mathrm{m}$ and $19.0 \mathrm{~cm} \mathrm{~s}^{-1}$ for $30<D<50 \mu \mathrm{m}$ ). This ambiguity in values used for sea fog deposition velocities leads to the greatest uncertainty in sea fog flux estimates.

In this study, it was assumed that all sea fog droplets measured with the fog monitor were deposited to the sea surface without changes in size distribution of LWC; however, due to evaporation and coalescence of sea fog droplets, their size and deposition velocities are subject to change, suggesting that the deposition velocities used here leads to the uncertainty in sea fog deposition flux estimates. The fog water sampler used in this study has a $50 \%$ efficiency collection diameter of $6 \mu \mathrm{m}$ under flow rate $3 \mathrm{~m} \mathrm{~s}^{-1}$ (Minami and Ishizaka, 1996). It is difficult, however, to calculate the precise collection efficiency of this fog sampler in this study, because the relative wind directions and the relative wind speeds change extremely with the movements of the ship (Sasakawa and Uematsu, 2005). Hence, the estimates of sea fog deposition fluxes in this study contain the uncertainties that are related to the changes in size distribution of LWC and the collection efficiency.

\section{Results and discussion}

\subsection{Meteorological conditions associated with sea fog occurrences}

Sea fog typically occurs as a result of cooling of humid air over a cold ocean surface (Lewis et al., 2004; Eugster, 2008). During the sampling period, sea fog occurred pre- dominantly when the dominant wind direction was southerly and/or southwesterly and air temperature dropped to its dew point (Fig. 2). This result indicates that the warm and humid air masses from the low and middle latitudes of the North Pacific Ocean passed over the cold sea surface of the subarctic western North Pacific Ocean and they were cooled down to a saturation temperature. Sea fog events, however, did not occur when sea surface temperature was higher than air temperature, although the dominant wind direction was southerly, suggesting that the difference between the air and sea surface temperatures is a key factor controlling sea fog formation (Cho et al., 2000).

According to previous studies (Cho et al., 2000; Fu et al., 2006; Tokinaga and Xie, 2009), the difference between air and sea surface temperatures is often observed to be positive in frequent sea fog occurrence regions, since the relatively cold sea surface temperature stabilizes the lower atmosphere, making a favorable condition for sea fog formation. Therefore, the meteorological conditions during the sea fog sampling period show that advection of warm and humid air masses from the subtropical North Pacific Ocean and the positive difference between air and sea surface temperatures make favorable conditions for sea fog occurrence over the subarctic western North Pacific Ocean.

\subsection{Effect of sea fog on particle number density}

Temporal variations of total LWC, particle number densities for aerosols in the range of $0.3-2.0 \mu \mathrm{m}$, and fog droplet size distribution for each of the 40 droplet size classes during the cruise are shown in Fig. 3. The total LWC varied from $<0.2-140 \mathrm{mg} \mathrm{m}^{-3}$. Mean particle number densities during non sea fog events were $25 \mathrm{~cm}^{-3}$ 
Table 1. Mean, 25th, 50th, and 75th percentile concentrations of major ionic species in aerosols $(n=11)$, rainwater $(n=7)$, and sea fog water $(n=15)$ collected over the subarctic western North Pacific during the cruise ${ }^{\mathrm{a}}$.

\begin{tabular}{|c|c|c|c|c|c|c|c|c|c|c|c|c|c|c|c|}
\hline & \multicolumn{4}{|c|}{ Aerosol $\left(\right.$ neq m$\left.^{-3}\right)$} & \multirow[b]{2}{*}{$\mathrm{n}^{\mathrm{c}}$} & \multicolumn{4}{|c|}{$\operatorname{Rain}\left(\mu \mathrm{eq} \mathrm{L}^{-1}\right)$} & \multirow[b]{2}{*}{$\mathrm{n}^{\mathrm{c}}$} & \multicolumn{4}{|c|}{ Sea fog $\left(\mu \mathrm{eq} \mathrm{L}^{-1}\right)$} & \multirow[b]{2}{*}{$\mathrm{n}^{\mathrm{c}}$} \\
\hline & Mean & $25 \mathrm{th}^{\mathrm{b}}$ & $50 \mathrm{th}^{\mathrm{b}}$ & $75 \mathrm{th}^{\mathrm{b}}$ & & Mean & $25 \mathrm{th}^{\mathrm{b}}$ & $50 \mathrm{th}^{\mathrm{b}}$ & $75 \mathrm{th}^{\mathrm{b}}$ & & Mean & $25 \mathrm{th}^{\mathrm{b}}$ & $50 \mathrm{th}^{\mathrm{b}}$ & $75 \mathrm{th}^{\mathrm{b}}$ & \\
\hline pH & - & - & - & - & - & 4.1 & 3.7 & 4.1 & 4.3 & 5 & 4.2 & 3.6 & 4.1 & 4.4 & 15 \\
\hline $\mathrm{Na}^{+}$ & 33 & 13 & 24 & 47 & 11 & 580 & 52 & 220 & 1300 & 7 & 390 & 78 & 190 & 400 & 15 \\
\hline $\mathrm{NH}_{4}^{+}$ & 5.6 & 4.1 & 5.4 & 6.5 & 11 & 25 & 8.4 & 18 & 41 & 7 & 22 & 8.5 & 22 & 33 & 15 \\
\hline $\mathrm{K}^{+}$ & 0.59 & 0.24 & 0.49 & 0.72 & 11 & 19 & 3.0 & 7.1 & 32 & 7 & 9.3 & 3.0 & 5.8 & 9.0 & 15 \\
\hline $\mathrm{Mg}^{2+}$ & 5.9 & 2.4 & 5.0 & 9.0 & 11 & 220 & 14 & 51 & 530 & 7 & 83 & 16 & 42 & 85 & 15 \\
\hline $\mathrm{Ca}^{2+}$ & 1.8 & 0.95 & 1.4 & 2.4 & 11 & 400 & 46 & 150 & 570 & 7 & 20 & 5.8 & 10 & 22 & 15 \\
\hline $\mathrm{Cl}^{-}$ & 28 & 7.0 & 21 & 39 & 11 & 1100 & 130 & 540 & 2500 & 7 & 400 & 80 & 190 & 420 & 15 \\
\hline $\mathrm{NO}_{3}^{-}$ & 2.5 & 1.3 & 2.3 & 3.1 & 11 & 7.9 & 1.6 & 5.4 & 13 & 7 & 50 & 7.6 & 51 & 75 & 15 \\
\hline $\mathrm{SO}_{4}^{2-}$ & 22 & 13 & 22 & 29 & 11 & 66 & 8.9 & 29 & 170 & 7 & 120 & 63 & 100 & 160 & 15 \\
\hline MSA & 0.62 & 0.24 & 0.43 & 0.67 & 11 & 0.42 & 0.10 & 0.18 & 0.86 & 6 & 6.2 & 0.93 & 3.2 & 9.5 & 15 \\
\hline nss-SO ${ }_{4}^{2-}$ & 18 & 9.9 & 17 & 27 & 11 & 5.5 & 1.9 & 4.9 & 15 & 5 & 72 & 39 & 50 & 100 & 14 \\
\hline nss- $\mathrm{K}^{+}$ & 0.068 & 0.018 & 0.024 & 0.091 & 9 & 7.0 & 1.9 & 2.7 & 10 & 7 & 1.7 & 0.80 & 1.1 & 2.7 & 14 \\
\hline nss-Ca ${ }^{2+}$ & 0.66 & 0.29 & 0.41 & 0.77 & 11 & 380 & 44 & 140 & 560 & 7 & 4.6 & 0.079 & 2.6 & 9.1 & 12 \\
\hline nss- $\mathrm{Mg}^{2+}$ & 0.12 & 0 & 0 & 0 & 2 & 95 & 15 & 59 & 290 & 5 & 1.1 & 0 & 0 & 1.3 & 5 \\
\hline nss- $\mathrm{Cl}^{-}$ & - & - & - & - & - & 420 & 20 & 190 & 840 & 7 & - & - & - & - & - \\
\hline
\end{tabular}

${ }^{a}$ Negative values that arise for non sea-salt ionic species as a result of analytical uncertainty and samples where concentration of each ionic component was below the detection limit have been included in the calculation of the average as 0 .

$\mathrm{b}$ These values indicate percentiles.

${ }^{\mathrm{c}}$ Sample number of each ionic component detected (or calculated) in aerosols, rainwater, and sea fog water.

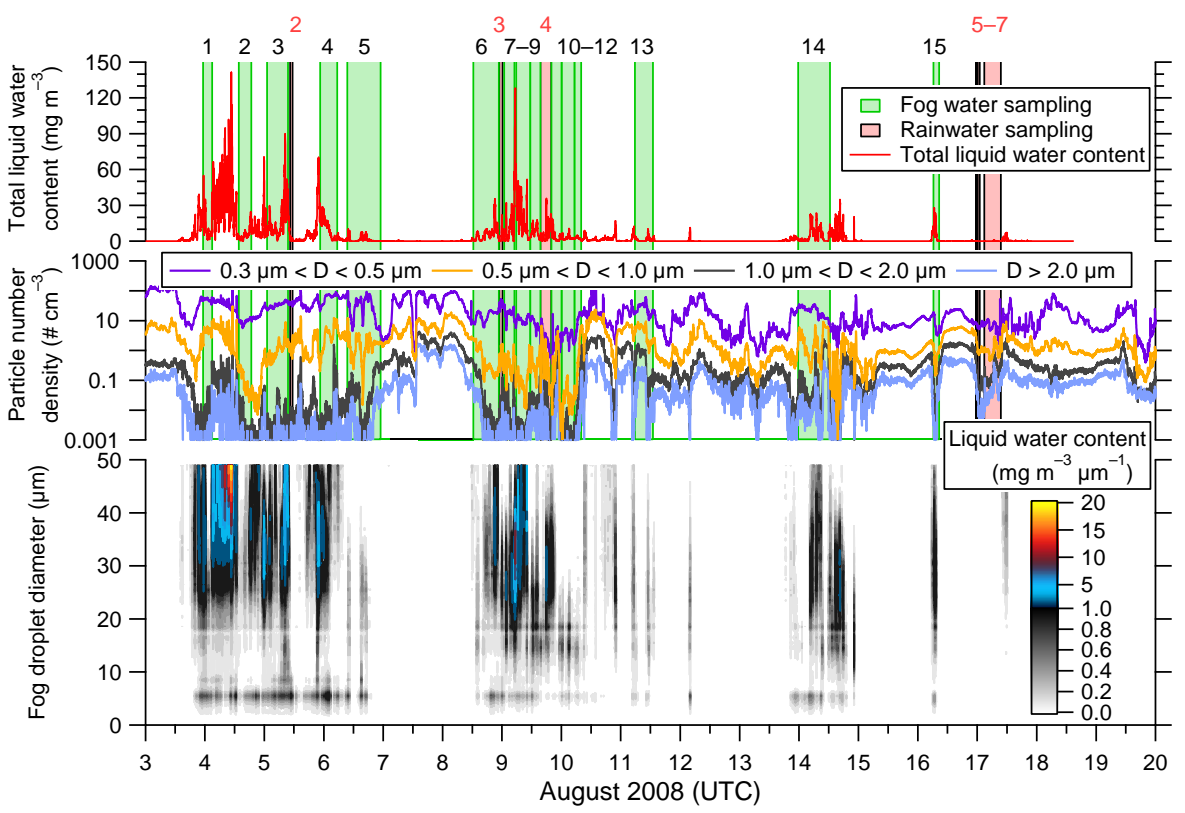

Fig. 3. Temporal variations of total LWC, particle number densities for aerosols in four size groups, and LWC for each of the 40 droplet size classes during the cruise. The green and pink shaded areas indicate sea fog water and rainwater sampling durations, respectively. The black and pink numbers indicate sea fog and rainwater sample number, respectively. When sea fog and rain events occurred simultaneously, only rainwater sample was collected. Then that sample was considered as a rainwater sample (i.e. rainwater sample number 3 and 4 ). Since rainwater sample number 1 was collected on 30 July, it was not presented here.

for aerosols in the range of $0.3<D<0.5 \mu \mathrm{m}, 2.6 \mathrm{~cm}^{-3}$ for $0.5<D<1.0 \mu \mathrm{m}, 0.53 \mathrm{~cm}^{-3}$ for $1.0<D<2.0 \mu \mathrm{m}$, and $0.17 \mathrm{~cm}^{-3}$ for $D>2.0 \mu \mathrm{m}$. In comparison, the mean particle number densities during sea fog events decreased by
$4 \%$ (mean particle number density $24 \mathrm{~cm}^{-3}$ ) for aerosols in the range of $0.3<D<0.5 \mu \mathrm{m}, 12 \%\left(2.3 \mathrm{~cm}^{-3}\right)$ for $0.5<D<1.0 \mu \mathrm{m}, 55 \%\left(0.24 \mathrm{~cm}^{-3}\right)$ for $1.0<D<2.0 \mu \mathrm{m}$, and $78 \%\left(0.038 \mathrm{~cm}^{-3}\right)$ for $D>2.0 \mu \mathrm{m}$. The differences 
(a) Aerosol

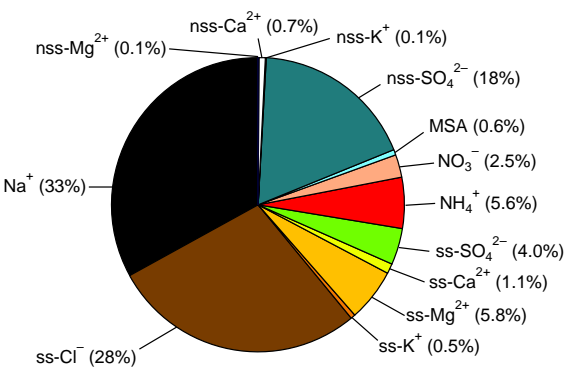

(b) Rainwater

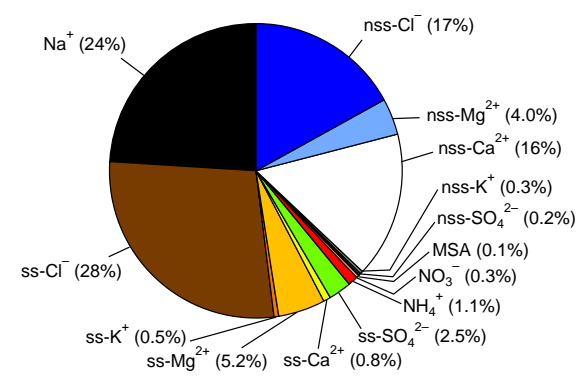

(c) Sea fog water

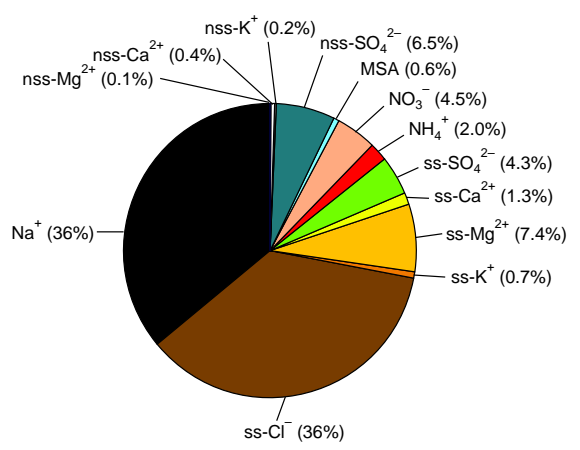

Fig. 4. Mean contributions of each major ionic component to total ionic concentration in (a) aerosols $(n=11)$, (b) rainwater $(n=7)$, and (c) sea fog water $(n=15)$ collected over the subarctic western North Pacific Ocean during the cruise.

Table 2. Mole equivalent ratios for major ionic species in aerosols, rainwater, and sea fog water, together with seawater ratios for comparison $^{\mathrm{a}}$.

\begin{tabular}{lllll}
\hline & Aerosol & Rain & Sea fog & Seawater $^{\mathrm{b}}$ \\
\hline $\mathrm{Cl}^{-} / \mathrm{Na}^{+}$ & 0.79 & 2.7 & 1.0 & 1.17 \\
$\mathrm{Mg}^{2+} / \mathrm{Na}^{+}$ & 0.19 & 0.42 & 0.19 & 0.22 \\
$\mathrm{~K}^{+} / \mathrm{Na}^{+}$ & 0.021 & 0.051 & 0.031 & 0.021 \\
$\mathrm{Ca}^{2+} / \mathrm{Na}^{+}$ & 0.073 & 1.2 & 0.069 & 0.044 \\
$\mathrm{SO}_{4}^{2-} / \mathrm{Na}^{+}$ & 1.4 & 0.15 & 0.92 & 0.12 \\
$\mathrm{nss}^{-} \mathrm{SO}_{4}^{2-} / \mathrm{Na}^{+}$ & 1.3 & 0.047 & 0.86 & - \\
$\mathrm{NO}_{3}^{-} / \mathrm{Na}^{+}$ & 0.099 & 0.029 & 0.43 & - \\
$\mathrm{NH}_{4}^{+} / \mathrm{Na}^{+}$ & 0.34 & 0.10 & 0.16 & - \\
$\mathrm{NO}_{3}^{-} / \mathrm{nss}^{-} \mathrm{SO}_{4}^{2-}$ & 0.19 & 0.81 & 0.57 & - \\
$\mathrm{NH}_{4}^{+} / \mathrm{nss}^{-} \mathrm{Ca}^{2+}$ & 12 & 0.14 & 28 & - \\
$\mathrm{NH}_{4}^{+} / \mathrm{nss}^{-\mathrm{Mg}^{2+}}$ & 17 & 0.82 & 11 & - \\
\hline
\end{tabular}

${ }^{\mathrm{a}}$ The samples with negative value of non sea-salt ionic component were excluded. ${ }^{b}$ Seawater ratios from Keene et al. (1986).

of mean particle number densities between two periods were statistically significant (Wilcoxon Signed Rank Test, $p=0.0005$ ), except that for aerosols in the range of $0.3<D<0.5 \mu \mathrm{m}$. In addition, the sea fog droplet size distributions during sea fog events were shifted towards the larger droplet sizes. These results suggest that particles with diam- eters larger than $0.5 \mu \mathrm{m}$ could act preferentially as $\mathrm{CN}$ for sea fog droplets (Sasakawa et al., 2003), and that the formation of liquid droplets by condensation of water vapor on pre-existed particles acting as $\mathrm{CN}$ leads to the acceleration of particle removal from the atmosphere (Pandis and Seinfeld, 1990).

\subsection{Chemical composition of aerosols, rainwater, and sea fog water}

Sea-salts $\left(\mathrm{Na}^{+}, \mathrm{Cl}^{-}\right.$, and ss-ions) were the dominant components in aerosols, rainwater, and sea fog water, representing approximately $72 \%, 61 \%$, and $86 \%$ of total ionic concentration, respectively (Fig. 4 and Table 1). In aerosols and sea fog water, the mole equivalent ratios of $\mathrm{Cl}^{-} / \mathrm{Na}^{+}$were slightly lower than that in seawater (Table 2), suggesting that $\mathrm{Cl}^{-} \mathrm{de}-$ pletion occurred through the volatilization of hydrogen chloride $(\mathrm{HCl})$ from sea-salt particles that became acidified by the incorporation of nitric $\left(\mathrm{HNO}_{3}\right)$ and/or sulfuric $\left(\mathrm{H}_{2} \mathrm{SO}_{4}\right)$ acids in the marine atmosphere (Graedel and Keene 1995; Andreae and Crutzen 1997), and that the acidified sea-salt particles acted as $\mathrm{CN}$ of sea fog droplets (Sasakawa and Uematsu, 2002; Raja et al., 2008). Furthermore, the $\mathrm{Mg}^{2+} / \mathrm{Na}^{+}$, $\mathrm{K}^{+} / \mathrm{Na}^{+}$, and $\mathrm{Ca}^{2+} / \mathrm{Na}^{+}$ratios in aerosols and sea fog water were similar or slightly higher than those in seawater, suggesting that most of $\mathrm{Mg}^{2+}, \mathrm{K}^{+}$and $\mathrm{Ca}^{2+}$ in aerosols and sea fog water were derived from sea-salt particles. 
Two volcanoes on the Aleutians erupted during the cruise. The eruption at Okmok volcano $\left(53.40^{\circ} \mathrm{N}, 168.17^{\circ} \mathrm{W}\right)$ started on 12 July 2008 and ended in late August 2008 (Larsen et al., 2009; Lu and Dzurisin, 2010), and Kasatochi volcano $\left(52.18^{\circ} \mathrm{N}, 175.51^{\circ} \mathrm{W}\right)$ became active on 7 August 2008 (Schmale et al., 2010). During the sampling period, air masses originated from the Asian continent and the Kamchatka Peninsula, indicating that these air masses were likely affected by anthropogenic and crustal sources as well as the eruptions of two volcanoes (Fig. 5a-c).

Unlike aerosol and sea fog water samples, the $\mathrm{Cl}^{-} / \mathrm{Na}^{+}$, $\mathrm{Mg}^{2+} / \mathrm{Na}^{+}, \mathrm{K}^{+} / \mathrm{Na}^{+}$, and $\mathrm{Ca}^{2+} / \mathrm{Na}^{+}$ratios in rainwater were much higher than those in seawater (Table 2). Atmospheric $\mathrm{HCl}$ are derived from sea-salt particles, volcanoes, and anthropogenic activities (e.g. fossil fuel combustion and incineration) (Graedel and Keene, 1995). Gioda et al. (2011) observed high $\mathrm{Cl}^{-} / \mathrm{Na}^{+}$ratios in rainwater (2.2) and cloud water (3.2), collected in Puerto Rico from December 2004 to March 2007, when ash from the Soufriere Hills volcano reached the sampling site. During the collection of rainwater samples, air masses originated from the Asian continent or the subtropical western North Pacific Ocean and thereafter swept over large regions of the Korean Peninsula and/or the Japanese Islands, indicating that these air masses were most likely affected by strong anthropogenic and crustal sources rather than by the influences of two volcanoes (Fig. 5b). The high $\mathrm{Cl}^{-} / \mathrm{Na}^{+}$ratio in rainwater thus is likely due to scavenging of $\mathrm{HCl}$ derived from sea-salt particles and/or anthropogenic source by rainwater. Sasakawa and Uematsu (2002) reported that $\mathrm{NH}_{4}^{+} / \mathrm{nss}^{-\mathrm{Ca}^{2+}}$ ratio in rainwater $(0.53)$ collected over the northwestern North Pacific $\left(34^{\circ} \mathrm{N}-48^{\circ} \mathrm{N}\right.$, $137^{\circ} \mathrm{E}-155^{\circ} \mathrm{E}$ ) from $15-29$ July 1998 , was two orders of magnitude lower than that in sea fog water (11), reflecting that mineral particles, such as calcium carbonate $\left(\mathrm{CaCO}_{3}\right)$, mainly existed over higher altitudes than those where sea fog appeared. While sea fog occurs near the sea surface (Fu et al., 2006) and scavenges only lower atmospheric substances (Ali et al., 2004), precipitation removes the substances existing in the whole air column in and below clouds (Deboudt et al., 2004). The high $\mathrm{Mg}^{2+} / \mathrm{Na}^{+}, \mathrm{K}^{+} / \mathrm{Na}^{+}$and $\mathrm{Ca}^{2+} / \mathrm{Na}^{+}$ ratios in rainwater therefore suggest that most of these ionic species in rainwater were derived from other sources, such as crustal materials and biomass burning, and that scavenging processes of aerosols by sea fog are different to those by rain.

\subsection{The $\mathrm{pH}$ of rainwater and sea fog water}

The $\mathrm{pH}$ values of rainwater and sea fog water varied from 3.5-4.5 and 3.4-5.9, with averages of 4.1 and 4.2, respectively (Table 1). Several compounds, such as $\mathrm{H}_{2} \mathrm{SO}_{4}, \mathrm{HNO}_{3}$, $\mathrm{HCl}, \mathrm{NH}_{3}$, and $\mathrm{CaCO}_{3}$, contribute to the acid-base balance of rainwater and fog water (Millet et al., 1996).

The mean nss- $\mathrm{Cl}^{-}$concentration in rainwater was two orders of magnitude greater than those of nss- $\mathrm{SO}_{4}^{2-}$ and $\mathrm{NO}_{3}^{-}$
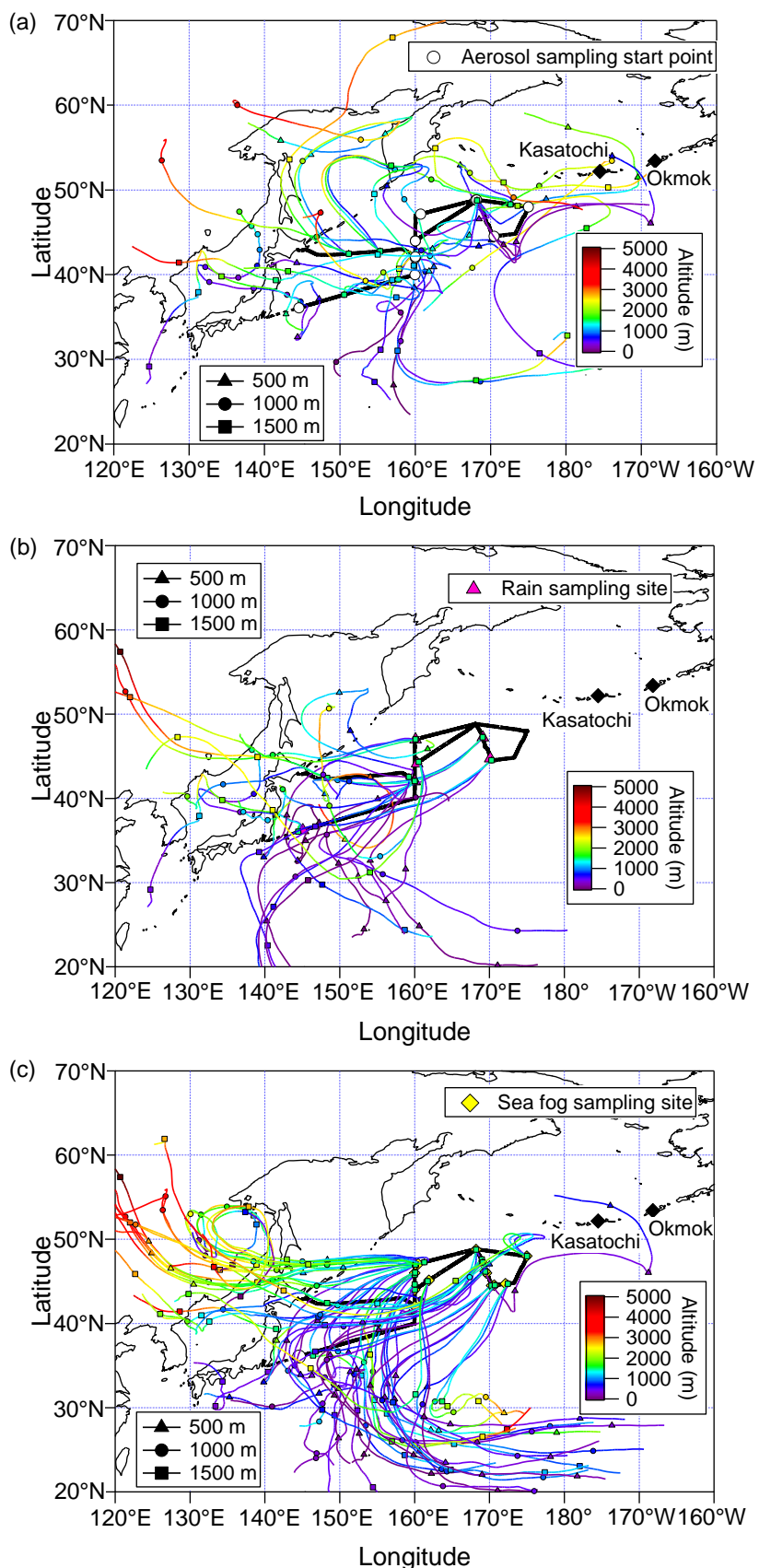

Fig. 5. The $168 \mathrm{~h}$ (7 days) air mass backward trajectories for starting altitudes of 500 (triangle symbols), 1000 (circle symbols) and $1500 \mathrm{~m}$ (square symbols) above ground level (a.g.l.) during the collections of aerosol (a), rain (b), and sea fog (c) samples were calculated from the Global Data Assimilation System (GDAS) database of the National Ocean and Atmospheric Administration (NOAA) and simulated by using the Hybrid Single-Particle Langrangian Integrated Trajectory (HY-SPLIT) model (web site http://www. arl.noaa.gov/ready/hysplit4.html). White circles, pink triangles and yellow diamonds indicate aerosol, rain and sea fog sampling locations during the cruise, respectively. Kasatochi and Okmok volcanoes are black diamonds. 

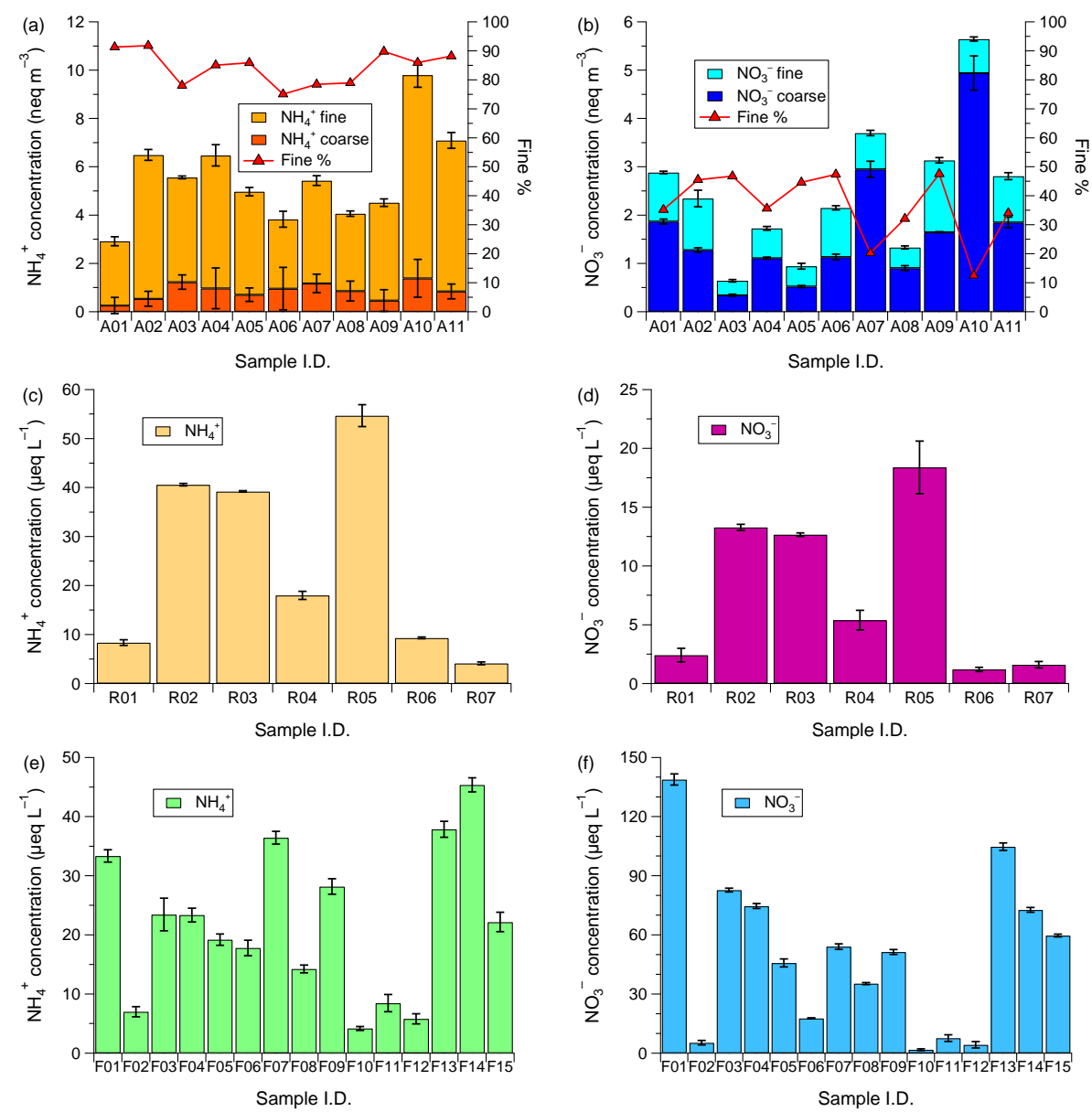

Fig. 6. Concentrations of $\mathrm{NH}_{4}^{+}$and $\mathrm{NO}_{3}^{-}$against sample I.D. in aerosols (a, b), rainwater (c, d), and sea fog water (e, f) collected over the subarctic western North Pacific Ocean. Solid triangle lines in (a) and (b) show the percentage of $\mathrm{NH}_{4}^{+}$and $\mathrm{NO}_{3}^{-}$in fine $(D<2.5 \mu \mathrm{m})$ aerosol particles.

(Table 1), suggesting that nss- $\mathrm{Cl}^{-}$exerted a larger influence on acidity of rainwater collected over the subarctic western North Pacific Ocean. Assuming the nss- $\mathrm{SO}_{4}^{2-}, \mathrm{NO}_{3}^{-}$, and $\mathrm{nss}^{-\mathrm{Cl}^{-}}$in rainwater existed in the form of free acids, the expected $\mathrm{pH}$ of rainwater was 3.4 , whereas the mean $\mathrm{pH}$ value measured in rainwater was 4.1 . This discrepancy indicates that rainwater had experienced some neutralization. From the difference between the sum of nss- $\mathrm{SO}_{4}^{2-}, \mathrm{NO}_{3}^{-}$, nss- $\mathrm{Cl}^{-}$, and the mean $\mathrm{H}^{+}$concentration obtained from the mean $\mathrm{pH}$ value, it was estimated that approximately $61 \%$ of these acidic substances was in neutralized forms. The mean concentrations of nss- $\mathrm{Ca}^{2+}$ and nss- $\mathrm{Mg}^{2+}$ in rainwater were 15 times and 3.8 times higher than that of $\mathrm{NH}_{4}^{+}$, respectively (Table 1). Moreover, the mole equivalent ratios of $\mathrm{NH}_{4}^{+} / \mathrm{nss}-$ $\mathrm{Ca}^{2+}$ and $\mathrm{NH}_{4}^{+} / \mathrm{nss}^{-\mathrm{Mg}^{2+}}$ in rainwater were lower than 1 , suggesting that nss- $\mathrm{Ca}^{2+}$ and nss- $\mathrm{Mg}^{2+}$ played key roles in neutralization of rainwater acidity.

In sea fog water, nss- $\mathrm{SO}_{4}^{2-}$ and $\mathrm{NO}_{3}^{-}$were the dominant acidic species (Fig. 4 and Table 1). The mole equivalent ratio of $\mathrm{NO}_{3}^{-} / \mathrm{nss}^{-\mathrm{SO}_{4}^{2-}}$ in sea fog water was 0.57 (Table 2). This result suggests that $\mathrm{nss}^{-\mathrm{SO}_{4}^{2-}}$ was the major component to lower the $\mathrm{pH}$ of sea fog, and that the $\mathrm{pH}$ of sea fog water was controlled by nss- $\mathrm{SO}_{4}^{2-}$ derived mainly from marine biological activity than that of rainwater since mean concentrations of methanesulfonic acid (MSA) and nss- $\mathrm{SO}_{4}^{2-}$ in sea fog water were an order of magnitude greater than those in rainwater (Table 1). For sea fog water, it was estimated that approximately $48 \%$ of nss- $\mathrm{SO}_{4}^{2-}$ and $\mathrm{NO}_{3}^{-}$was in neutralized forms. While nss- $\mathrm{Ca}^{2+}$ and nss- $\mathrm{Mg}^{2+}$ were the dominant neutralization substances in rainwater, $\mathrm{NH}_{4}^{+}$was the major basic component in sea fog water (Fig. 4 and Table 2), suggesting that neutralization of sea fog water was predominantly caused by $\mathrm{NH}_{4}^{+}$, and that $\mathrm{nss}-\mathrm{SO}_{4}^{2-}$ and $\mathrm{NO}_{3}^{-}$in sea fog water were probably in fully or partially neutralized forms, such as ammonium sulfate $\left(\left(\mathrm{NH}_{4}\right)_{2} \mathrm{SO}_{4}\right)$, ammonium bisulfate $\left(\mathrm{NH}_{4} \mathrm{HSO}_{4}\right)$ and ammonium nitrate $\left(\mathrm{NH}_{4} \mathrm{NO}_{3}\right)$. 


\subsection{Concentrations of $\mathrm{NH}_{4}^{+}$and $\mathrm{NO}_{3}^{-}$in aerosols, rainwater, and sea fog water}

\subsubsection{Aerosols}

Total concentrations of $\mathrm{NH}_{4}^{+}$and $\mathrm{NO}_{3}^{-}$in bulk (fine + coarse) aerosols ranged from $2.9-9.8 \mathrm{neq} \mathrm{m}^{-3}$ and $0.64-$ 5.6 neq $^{-3}$, respectively (Fig. $6 \mathrm{a}$ and b). Mean concentrations of aerosol inorganic $\mathrm{N}$ species were $5.6 \mathrm{neq}^{-3}$ for $\mathrm{NH}_{4}^{+}$and $2.5 \mathrm{neq} \mathrm{m}^{-3}$ for $\mathrm{NO}_{3}^{-}$, accounting for $\sim 70 \%$ by $\mathrm{NH}_{4}^{+}$and $\sim 30 \%$ by $\mathrm{NO}_{3}^{-}$of aerosol total inorganic $\mathrm{N}$ (i.e. $\mathrm{TIN}=\mathrm{NH}_{4}^{+}+\mathrm{NO}_{3}^{-}$) (Table 1$)$. Ammonium is primarily associated with fine mode aerosol and produced by heterogeneous reactions involving $\mathrm{NH}_{3}$ derived from intensive agricultural activity (Aneja et al., 2001), biomass burning (Andreae and Merlet, 2001) and a relatively weak marine source (Jickells et al., 2003). It is also known that $\mathrm{NO}_{3}^{-}$in the marine atmosphere is predominantly associated with coarse mode aerosol as a result of a chemical reaction between $\mathrm{HNO}_{3}$ derived primarily from $\mathrm{NO}_{\mathrm{x}}$ emissions from combustion processes and sea-salt (Andreae and Crutzen, 1997). Mean percentages of total aerosol concentration in the fine mode for $\mathrm{NH}_{4}^{+}$and $\mathrm{NO}_{3}^{-}$were $\sim 84 \%$ and $\sim 36 \%$, respectively. These values were similar to the results of Nakamura et al. (2005), who reported the size distributions of $\mathrm{NH}_{4}^{+}$and $\mathrm{NO}_{3}^{-}$in aerosols collected over the East China Sea.

During the sampling period, over a dozen sea fog events occurred and aerosol samples, A03-A06 and A08-A09, were largely affected by these fog appearance. As shown in Figs. $6 \mathrm{a}$ and $6 \mathrm{~b}, \mathrm{NO}_{3}^{-}$, which mainly existed in coarse mode aerosols, was more efficiently scavenged by sea fog than $\mathrm{NH}_{4}^{+}$, showing that coarse particles act predominantly as $\mathrm{CN}$ of sea fog droplets rather than the fine particles (see section 3.6). Sasakawa and Uematsu (2002) reported that mean concentrations of $\mathrm{NH}_{4}^{+}$and $\mathrm{NO}_{3}^{-}$in aerosols collected over the northwestern North Pacific Ocean $\left(34^{\circ} \mathrm{N}-48^{\circ} \mathrm{N}, 137^{\circ} \mathrm{E}-\right.$ $155^{\circ} \mathrm{E}$ ) from $15-29 \mathrm{July} 1998$, were $11 \pm 2.9 \mathrm{neq} \mathrm{m}^{-3}$ and $3.7 \pm 2.2$ neq $^{-3}$, respectively. In comparison, the mean aerosol $\mathrm{NH}_{4}^{+}$and $\mathrm{NO}_{3}^{-}$concentrations in this study were a factor of 2 and 1.5 lower than their results, respectively. The low mean $\mathrm{NH}_{4}^{+}$and $\mathrm{NO}_{3}^{-}$concentrations in aerosols thus are likely due to strong influences of sea fog.

\subsubsection{Rainwater}

When sea fog and rain events occurred simultaneously, only rainwater was collected (Fig. 3). That sample was then considered as a rainwater sample (i.e. rainwater sample number 3 and 4), although the rainwater sample contains sea fog water as well as rainwater, since sea fog water is deposited by rainwater during that time. Concentrations of $\mathrm{NH}_{4}^{+}$and $\mathrm{NO}_{3}^{-}$in rainwater ranged from $4.1-55 \mu \mathrm{eq} \mathrm{L}^{-1}$ and $1.2-18 \mu \mathrm{eq} \mathrm{L}^{-1}$, respectively (Figs. 6c and 6d). Mean concentrations of inorganic $\mathrm{N}$ species were $25 \mu \mathrm{eq} \mathrm{L}^{-1}$ for $\mathrm{NH}_{4}^{+}$and $7.9 \mu \mathrm{eq} \mathrm{L}^{-1}$ for $\mathrm{NO}_{3}^{-}$(Table 1). These values were in the range of the
Table 3. Sea fog water/rainwater ratios for major ionic species in terms of concentrations $\left(\mu \mathrm{eq} \mathrm{L}^{-1}\right)$.

\begin{tabular}{|c|c|}
\hline & $\begin{array}{l}\text { Sea fog water/ } \\
\text { Rainwater }\end{array}$ \\
\hline $\mathrm{Na}^{+}$ & 0.67 \\
\hline $\mathrm{NH}_{4}^{+}$ & 0.88 \\
\hline ss-K $^{+}$ & 0.63 \\
\hline ss-Mg ${ }^{2+}$ & 0.66 \\
\hline ss-Ca ${ }^{2+}$ & 0.77 \\
\hline $\mathrm{ss}_{-} \mathrm{Cl}^{-}$ & 0.59 \\
\hline $\mathrm{NO}_{3}^{-}$ & 6.3 \\
\hline ss- $\mathrm{SO}_{4}^{2-}$ & 0.79 \\
\hline $\mathrm{MSA}^{4}$ & 15 \\
\hline nss-SO ${ }_{4}^{2-}$ & 13 \\
\hline$n s s-K^{+}$ & 0.24 \\
\hline nss-Ca ${ }^{2+}$ & 0.012 \\
\hline nss-Mg ${ }^{2+}$ & 0.012 \\
\hline
\end{tabular}

observed $\mathrm{NH}_{4}^{+}(1.7-67 \mu \mathrm{eq} \mathrm{L}-1)$ and $\mathrm{NO}_{3}^{-}\left(2.4-26 \mu\right.$ eq $\left.\mathrm{L}^{-1}\right)$ concentrations in rainwater collected over the northwestern North Pacific Ocean $\left(34^{\circ} \mathrm{N}-48^{\circ} \mathrm{N}, 137^{\circ} \mathrm{E}-155^{\circ} \mathrm{E}\right)$ from $15-$ 29 July 1998 (Sasakawa and Uematsu, 2002). Inorganic $\mathrm{N}$ in rainwater was composed of $\sim 77 \% \mathrm{NH}_{4}^{+}$and $\sim 23 \% \mathrm{NO}_{3}^{-}$ (mean values), suggesting that $\mathrm{NH}_{4}^{+}$is more abundant in rainwater collected over the subarctic western North Pacific Ocean, and that it is a more important inorganic $\mathrm{N}$ species supplied by wet deposition.

\subsubsection{Sea fog water}

Concentrations of $\mathrm{NH}_{4}^{+}$and $\mathrm{NO}_{3}^{-}$in sea fog water ranged from $4.2-45 \mu \mathrm{eq} \mathrm{L}^{-1}$ and $1.8-139 \mu \mathrm{eq} \mathrm{L}^{-1}$, respectively (Fig. 6e and f). Contributions of $\mathrm{NH}_{4}^{+}$and $\mathrm{NO}_{3}^{-}$to TIN in sea fog water were found to represent $\sim 39 \%$ (mean concentration $22 \mu \mathrm{eq} \mathrm{L}^{-1}$ ) and $\sim 61 \%$ (mean concentration $50 \mu \mathrm{eq} \mathrm{L}^{-1}$ ), respectively (Table 1 ). Sasakawa and Uematsu (2002) reported that mean $\mathrm{NH}_{4}^{+}$and $\mathrm{NO}_{3}^{-}$concentrations in sea fog water collected over the northwestern North Pacific Ocean $\left(34^{\circ} \mathrm{N}-48^{\circ} \mathrm{N}, 137^{\circ} \mathrm{E}-155^{\circ} \mathrm{E}\right)$ from $15-29$ July 1998 , were $25 \pm 17 \mu \mathrm{eq} \mathrm{L}^{-1}$ and $25 \pm 22 \mu \mathrm{eq} \mathrm{L} \mathrm{L}^{-1}$, respectively. The mean $\mathrm{NH}_{4}^{+}$concentration observed in this study was comparable to their result; however, the mean concentration of $\mathrm{NO}_{3}^{-}$was a factor of 2 higher than their result for $\mathrm{NO}_{3}^{-}$. This different concentration is likely attributable to the duration, frequency of sea fog events, and changes in the quality of air mass.

\subsection{Difference of scavenging process between rain and sea fog}

Mean concentrations of $\mathrm{NO}_{3}^{-}$, MSA, and nss- $\mathrm{SO}_{4}^{2-}$ in sea fog water were higher than those in rainwater (Tables 1 and 3), suggesting that they were more effectively scavenged by sea 
fog droplets with their higher surface-to-volume ratios and longer atmospheric residence times (Sasakawa and Uematsu, 2002; Sasakawa and Uematsu, 2005; Gioda et al., 2011).

The sea fog water/rainwater ratio for $\mathrm{NH}_{4}^{+}$was 0.88 (Table 3), suggesting that $\mathrm{NH}_{4}^{+}$was not scavenged by sea fog as efficiently as $\mathrm{NO}_{3}^{-}$, MSA, and nss- $\mathrm{SO}_{4}^{2-}$. The mean $\mathrm{NO}_{3}^{-}$ concentration in sea fog water was 6.3 times higher than that in rainwater, whereas the mean $\mathrm{NH}_{4}^{+}$concentration in sea fog water was similar to that in rainwater. Sasakawa et al. (2003) reported that coarse particles (e.g. sea-salt particles and $\mathrm{NaNO}_{3}$ ) act predominantly as $\mathrm{CN}$ of sea fog droplets rather than $\mathrm{NH}_{4}^{+}$and nss- $\mathrm{SO}_{4}^{2-}$ particles, such as $\left(\mathrm{NH}_{4}\right)_{2} \mathrm{SO}_{4}$ and $\mathrm{NH}_{4} \mathrm{HSO}_{4}$ since aerosol $\mathrm{NH}_{4}^{+}$and nss- $\mathrm{SO}_{4}^{2-}$ are largely associated with the fine mode $(D<2.5 \mu \mathrm{m})$ particles (Nakamura et al., 2005). In addition, $\mathrm{NH}_{3}$ readily reacts with acids in the atmosphere to form $\mathrm{NH}_{4}^{+}$aerosols that can act as cloud CN (Quinn et al., 1987). In this study, it was observed that larger particles $(D>0.5 \mu \mathrm{m})$ preferentially became activated and the fog droplet size distribution was shifted towards the larger droplet sizes (Fig. 3), and that $\mathrm{NH}_{4}^{+}$and $\mathrm{NO}_{3}^{-}$were largely associated with fine and coarse mode aerosols, respectively (Fig. 6a and b). Therefore, higher $\mathrm{NO}_{3}^{-}$concentration in sea fog water than in rainwater is likely due to preferential behaviors of coarse particles as $\mathrm{CN}$ in sea fog.

While MSA is formed exclusively from dimethylsulfide (DMS) produced by phytoplankton in the ocean, non seasalt $\mathrm{SO}_{4}^{2-}$ has a variety of sources, including DMS oxidation, volcanic and industrial sulfur emissions (Gondwe et al., 2003). Dimethylsulfide is emitted into the atmosphere, where it undergoes chemical transformation to eventually form gaseous (e.g. MSA and $\mathrm{SO}_{2}$ ) and/or particulate (e.g. MSA and nss-SO ${ }_{4}^{2-}$ ) sulfur species (e.g. Charlson et al., 1987; Bardouki et al., 2003). Mean concentrations of MSA and nss$\mathrm{SO}_{4}^{2-}$ in sea fog water were 15 times and 13 times higher than those in rainwater, respectively (Tables 1 and 3). During the sampling period, SeaWiFS satellite images revealed high chlorophyll a levels (http://oceancolor.gsfc.nasa.gov) in the subarctic western North Pacific Ocean (see Supplement, Fig. S1). Considering sea fog occurs near the sea surface where DMS is emitted, these results suggest that sea fog scavenged biogenic sulfur species more effectively than rain (Sasakawa and Uematsu, 2005).

If aerosol particles exert the primary influence as $\mathrm{CN}$ of sea fog droplets, the mole equivalent ratios between aerosols and sea fog water would be similar (Sasakawa and Uematsu, 2002; Gioda et al., 2011). The mole equivalent ratio of $\mathrm{NO}_{3}^{-} / \mathrm{Na}^{+}$in sea fog water was higher than that in aerosols (Table 2). This result suggests that not only aerosol $\mathrm{NO}_{3}^{-}$, but also gaseous $\mathrm{HNO}_{3}$ was scavenged by sea fog water. Nitric acid is highly soluble in water. Once a large amount of liquid water has amassed, the gas phase $\mathrm{HNO}_{3}$ is rapidly dissolved (Fahey et al., 2005). In order to estimate the fraction of gaseous $\mathrm{HNO}_{3}$ scavenged by sea fog water, the $\mathrm{NO}_{3}^{-} / \mathrm{Na}^{+}$ ratios in aerosols was compared to those in sea fog water

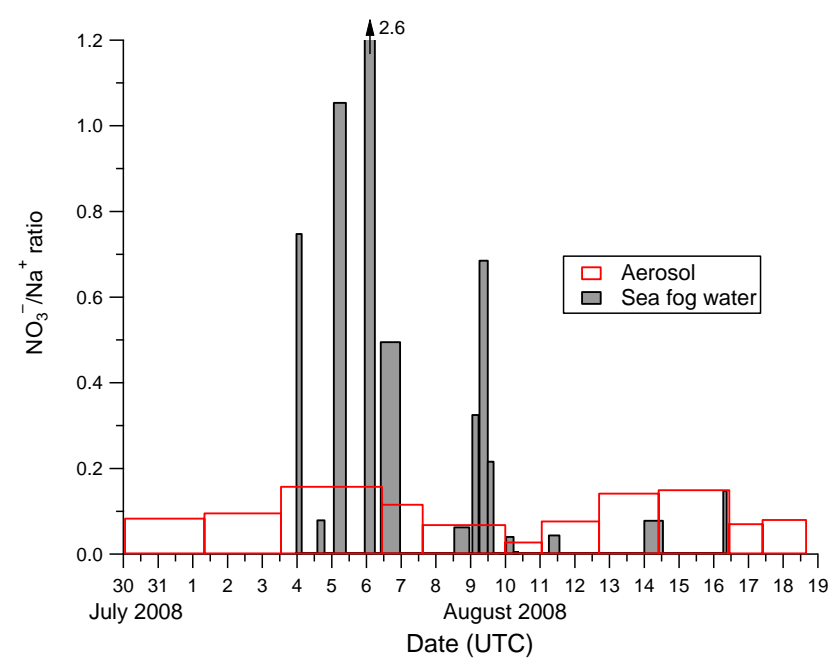

Fig. 7. The mole equivalent ratios of $\mathrm{NO}_{3}^{-} / \mathrm{Na}^{+}$in aerosols (red open bars) and sea fog water (gray bars) during the cruise. The widths of red open and gray bars indicate the sampling duration of aerosol and sea fog water samples, respectively.

(Fig. 7). In 8 sea fog samples, the higher $\mathrm{NO}_{3}^{-} / \mathrm{Na}^{+}$ratios than in aerosols were observed when air masses originated from the Asian continent or from the subtropical western North Pacific Ocean circulated around the vicinity of the Japanese Islands and thereafter reached the sea fog sampling sites (Fig. 5c). In this study, it was estimated that 25-94\% (mean $74 \%$ ) of $\mathrm{NO}_{3}^{-}$in the 8 sea fog water samples was derived from the dissolution of $\mathrm{HNO}_{3}$, suggesting that sea fog over the subarctic western North Pacific Ocean is an important removal mechanism for gas phase $\mathrm{HNO}_{3}$. In comparison, the $\mathrm{NH}_{4}^{+} / \mathrm{Na}^{+}$ratios in sea fog water for all periods were lower than those in aerosols (Fig. S2), indicating that sea-salt particles exerted a greater influence on the $\mathrm{NH}_{4}^{+} / \mathrm{Na}^{+}$ratios in sea fog water due to condensation occurred preferably on coarse particles as mentioned above.

\subsection{Contributions of dry, wet, and sea fog deposition to atmospheric input of nitrogen to the subarctic western North Pacific Ocean}

The measured $\mathrm{NH}_{4}^{+}$and $\mathrm{NO}_{3}^{-}$concentrations in aerosols, rainwater, and sea fog water were converted into fluxes using the equations described in Sect. 2.6. For sea fog water flux, the mean LWC for each of the 40 droplet size classes measured by the fog monitor during each sea fog event was used (Fig. 8). Temporal variations of dry, wet, and sea fog deposition fluxes for $\mathrm{NH}_{4}^{+}$and $\mathrm{NO}_{3}^{-}$during the sampling period are shown in Fig. 9. The estimated dry deposition fluxes for atmospheric inorganic $\mathrm{N}$ species ranged from $0.67-3.1 \mu \mathrm{mol} \mathrm{m}^{-2} \mathrm{~d}^{-1}$ for $\mathrm{NH}_{4}^{+}$and from $0.62-8.6 \mu \mathrm{mol} \mathrm{m}^{-2} \mathrm{~d}^{-1}$ for $\mathrm{NO}_{3}^{-}$, contributing $\sim 43 \%$ by $\mathrm{NH}_{4}^{+}$and $\sim 57 \%$ by $\mathrm{NO}_{3}^{-}$to the dry deposition flux for TIN. Mean dry deposition fluxes for $\mathrm{NH}_{4}^{+}$and $\mathrm{NO}_{3}^{-}$were 
Table 4. Mean dry, wet, sea fog, and total deposition fluxes of $\mathrm{NH}_{4}^{+}$and $\mathrm{NO}_{3}^{-}$, and the contribution of each deposition to total inorganic $\mathrm{N}$ input in the subarctic western North Pacific Ocean during the cruise.

\begin{tabular}{lllll}
\hline & $\begin{array}{l}\text { Dry deposition } \\
\left.(\mu \mathrm{mol} \mathrm{m})^{-2} \mathrm{~d}^{-1}\right)\end{array}$ & $\begin{array}{l}\text { Wet deposition } \\
\left.(\mu \mathrm{mol} \mathrm{m})^{-2} \mathrm{~d}^{-1}\right)\end{array}$ & $\begin{array}{l}\text { Sea fog deposition } \\
\left(\mu \mathrm{mol} \mathrm{m}^{-2} \mathrm{~d}^{-1}\right)\end{array}$ & $\begin{array}{l}\text { Total deposition } \\
\left(\mu \mathrm{mol} \mathrm{m} \mathrm{d}^{-1}\right)\end{array}$ \\
\hline $\mathrm{NH}_{4}^{+}$ & $1.9(4.1 \%)$ & $25(54 \%)$ & $2.1(4.6 \%)$ & $29(63 \%)$ \\
$\mathrm{NO}_{3}^{-}$ & $3.0(6.5 \%)$ & $8.0(17 \%)$ & $5.7(12 \%)$ & $17(37 \%)$ \\
$\mathrm{TIN}^{\mathrm{a}}$ & $4.9(11 \%)$ & $33(72 \%)$ & $7.8(17 \%)$ & $46(100 \%)$ \\
$\mathrm{TIN}^{\mathrm{b}}$ & $12(23 \%)$ & $33(62 \%)$ & $7.8(15 \%)$ & $53(100 \%)$ \\
\hline
\end{tabular}

a TIN represents total inorganic nitrogen. In this study, total inorganic nitrogen is defined as including $\mathrm{NH}_{4}^{+}$and $\mathrm{NO}_{3}^{-}$; i.e. $\mathrm{TIN}=\mathrm{NH}_{4}^{+}+\mathrm{NO}_{3}^{-}$.

$\mathrm{b}$ The mean dry, wet, and sea fog deposition fluxes for TIN and the contribution of each deposition to TIN input when the dry deposition fluxes for gaseous $\mathrm{NH}_{3}\left(2.0 \mu \mathrm{mol} \mathrm{m}{ }^{-2} \mathrm{~d}^{-1}\right)$ and $\mathrm{HNO}_{3}\left(4.7 \mu \mathrm{mol} \mathrm{m}{ }^{-2} \mathrm{~d}^{-1}\right)$ reported by Zhang et al. (2010) are included.
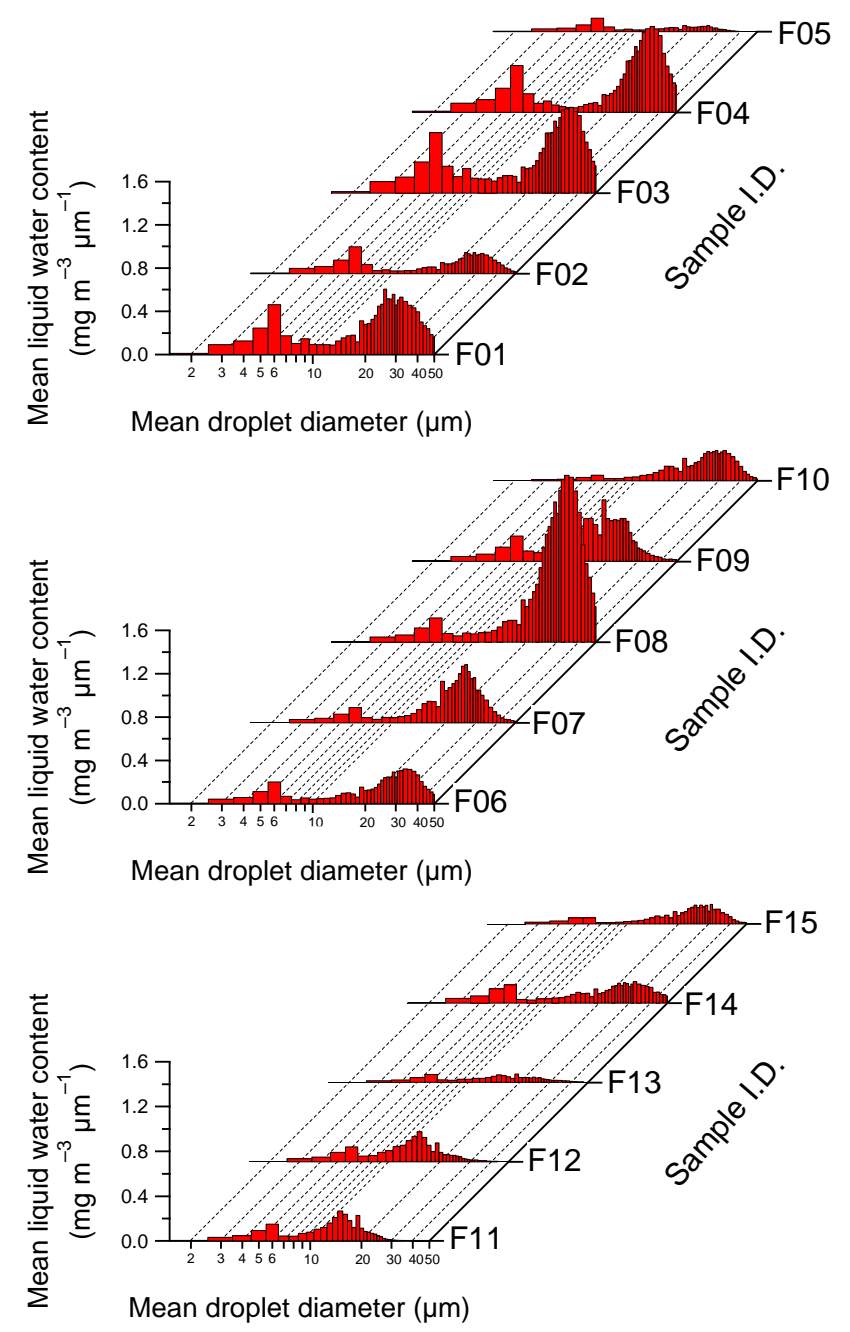

Fig. 8. Variations of mean LWC for each sea fog event as a function of mean droplet diameter during the cruise. estimated to be $1.9 \mu \mathrm{mol} \mathrm{m}^{-2} \mathrm{~d}^{-1}$ and $3.0 \mu \mathrm{mol} \mathrm{m}^{-2} \mathrm{~d}^{-1}$, respectively. Although the mean concentration of total $\mathrm{NH}_{4}^{+}$in aerosols collected over the subarctic western North Pacific Ocean was approximately 2 times higher than that of total $\mathrm{NO}_{3}^{-}$(Table 1), inorganic $\mathrm{N}$ supplied to surface waters by atmospheric dry deposition was mainly from $\mathrm{NO}_{3}^{-}$that was largely associated with coarse mode particles, since fluxes to the ocean are dominated by the coarse mode, resulting in $\mathrm{NO}_{3}^{-}$being deposited much more rapidly (Fig. 6a and b). In this study, dry deposition fluxes of gaseous inorganic $\mathrm{N}$ species such as $\mathrm{NH}_{3}$ and $\mathrm{HNO}_{3}$ were not estimated, resulting in the underestimate of dry deposition fluxes. Due to the lack of observational data for gaseous inorganic $\mathrm{N}$ species over the western North Pacific Ocean, we used the results of Zhang et al. (2010) to estimate the contributions of gaseous inorganic $\mathrm{N}$ to dry deposition fluxes, who reported that dry deposition fluxes for $\mathrm{NH}_{3}$ and $\mathrm{HNO}_{3}$ were estimated to be $2.0 \mu \mathrm{mol} \mathrm{m} \mathrm{m}^{-2} \mathrm{~d}^{-1}$ and $4.7 \mu \mathrm{mol} \mathrm{m}{ }^{-2} \mathrm{~d}^{-1}$ respectively over the East China Sea in July using the MM5/CMAQ model with the 2004 national emission inventory of China. Assuming that the same amounts of $\mathrm{NH}_{3}$ and $\mathrm{HNO}_{3}$ are deposited over the sampling region of this study, the contribution of dry deposition flux to mean total (dry + wet + sea fog) deposition flux for TIN would increase from $11 \%$ to $23 \%$ (Table 4 ). However, it is worth noting that the dry deposition fluxes for $\mathrm{NH}_{3}$ and $\mathrm{HNO}_{3}$ would decrease as the distance from shore increased since land-derived gaseous inorganic $\mathrm{N}$ species are probably transformed to aerosol particles through acid-base reaction and/or absorption on sea-salt particles during their transport over the ocean.

Wet deposition of atmospheric inorganic $\mathrm{N}$ was highly variable from one event to the next depending on the concentrations of $\mathrm{NH}_{4}^{+}$and $\mathrm{NO}_{3}^{-}$in the precipitation as well as the frequency and amount of precipitation. Wet deposition fluxes of atmospheric inorganic $\mathrm{N}$ species ranged from 3.5 to 98 (mean 25) $\mu \mathrm{mol} \mathrm{m} \mathrm{m}^{-2} \mathrm{~d}^{-1}$ for $\mathrm{NH}_{4}^{+}$and from 1.0 to 32 (mean 8.0) $\mu \mathrm{mol} \mathrm{m}{ }^{-2} \mathrm{~d}^{-1}$ for $\mathrm{NO}_{3}^{-}$, accounting for $\sim 77 \%$ by $\mathrm{NH}_{4}^{+}$ and $\sim 23 \%$ by $\mathrm{NO}_{3}^{-}$of TIN from wet deposition flux. While 
$\mathrm{NO}_{3}^{-}$was the dominant inorganic $\mathrm{N}$ species in dry deposition, inorganic $\mathrm{N}$ supplied to surface waters by atmospheric wet deposition was predominantly by $\mathrm{NH}_{4}^{+}(72-89 \%$ of the wet deposition fluxes for TIN).

Likewise wet deposition, sea fog deposition of atmospheric inorganic $\mathrm{N}$ was highly variable depending on the size distribution of LWC, the amount of LWC, and the duration of sea fog event as well as the concentrations of $\mathrm{NH}_{4}^{+}$ and $\mathrm{NO}_{3}^{-}$in the sea fog water. The estimated sea fog deposition fluxes for atmospheric inorganic $\mathrm{N}$ species ranged from $0.18-5.2 \mu \mathrm{mol} \mathrm{m}^{-2} \mathrm{~d}^{-1}$ for $\mathrm{NH}_{4}^{+}$and from $0.13-22$ $\mu \mathrm{mol} \mathrm{m}{ }^{-2} \mathrm{~d}^{-1}$ for $\mathrm{NO}_{3}^{-}$, contributing $\sim 39 \%$ by $\mathrm{NH}_{4}^{+}$and $\sim 61 \%$ by $\mathrm{NO}_{3}^{-}$to the sea fog deposition flux for TIN. Mean sea fog deposition fluxes for $\mathrm{NH}_{4}^{+}$and $\mathrm{NO}_{3}^{-}$were estimated to be $2.1 \mu \mathrm{mol} \mathrm{m}{ }^{-2} \mathrm{~d}^{-1}$ and $5.7 \mu \mathrm{mol} \mathrm{m} \mathrm{m}^{-2} \mathrm{~d}^{-1}$, respectively, indicating that inorganic $\mathrm{N}$ supplied to surface waters by sea fog deposition was mainly by $\mathrm{NO}_{3}^{-}$, since aerosol $\mathrm{NO}_{3}^{-}$and $\mathrm{HNO}_{3}$ were scavenged more effectively by sea fog.

While dry deposition is a continuous process occurring at all times over all surfaces, wet and sea fog deposition are highly episodic. The relative importance of dry, wet, and sea fog deposition obviously varies greatly on short time scales, and varies spatially on longer time scales with global rainfall patterns (Jickells, 2006) and trends in fog frequency (Gultepe et al., 2007). Mean total (dry + wet + sea fog) deposition flux of atmospheric TIN in the subarctic western North Pacific Ocean was estimated to be $46 \mu \mathrm{mol} \mathrm{m}{ }^{-2} \mathrm{~d}^{-1}$, with $72 \%$ of this in the form of wet deposition (Table 4). This indicates that wet deposition plays an important role in the supply of atmospheric inorganic $\mathrm{N}$ to the subarctic western North Pacific Ocean compared to dry and sea fog deposition, although the relative contributions are highly variable. The estimate of the proportion of atmospheric $\mathrm{N}$ input via wet deposition were comparable to previously published values: the Pacific $86 \%$ (Duce et al., 1991), the Atlantic 78-85\% (Baker et al., 2010), and the world oceans $71 \%$ (Duce et al., 1991).

Fog can lead to substantial $\mathrm{N}$ deposition if the event persists long enough (several hours) with sufficient LWC (dense fog), particularly for those formed in continental air masses (Jordan and Talbot, 2000). Although the mean contribution of sea fog deposition to total atmospheric TIN input to the subarctic western North Pacific Ocean was $\sim 17 \%$ (Table 4 ), in some cases, atmospheric TIN deposition flux via sea fog exceeded the combined dry and wet deposition flux of TIN (Fig. 9), suggesting that sea fog can deposit as much $\mathrm{N}$ as a high $\mathrm{N}$ deposited by rain event, and that sea fog is an important transfer process for atmospheric inorganic $\mathrm{N}$ from the marine atmosphere to the subarctic western North Pacific Ocean.

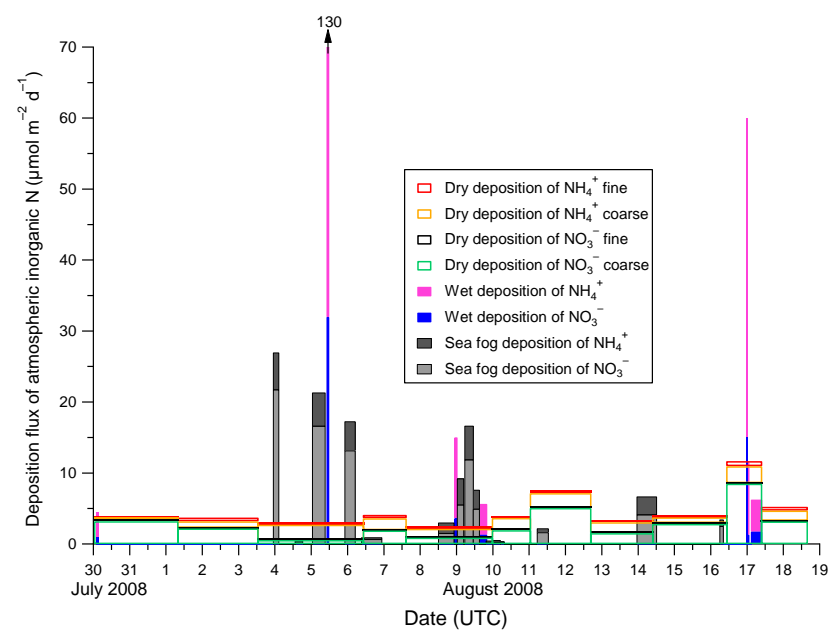

Fig. 9. Temporal variations of dry, wet, and sea fog deposition fluxes for $\mathrm{NH}_{4}^{+}$and $\mathrm{NO}_{3}^{-}$over the subarctic western North Pacific Ocean during the cruise.

\subsection{Potential impact of atmospheric inorganic nitrogen deposition on primary production over the subarctic western North Pacific Ocean}

The potential impact of atmospheric deposition on marine ecosystems depends on the nutrient status of the receiving waters, and is related to both the total amount and ratio of atmospherically supplied nutrients and to the limiting nutrient for the existing local water column (Baker et al., 2006). It is known that $\mathrm{NH}_{4}^{+}$and $\mathrm{NO}_{3}^{-}$can be readily utilized by a variety of aquatic microorganisms (Gilbert et al., 1991). In order to evaluate the impact of atmospheric $\mathrm{N}$ on the marine ecosystem, potential primary production was estimated using the result for total deposition flux of TIN and the Redfield $\mathrm{C} / \mathrm{N}$ ratio of 6.6. The average elemental $\mathrm{C} / \mathrm{N}$ requirement for many plankton species and for bulk organic matter in the oceans has been found to be relatively constant at $\sim 6.6$ $\left(\mathrm{mol} \mathrm{mol}^{-1}\right)$ (Redfield, 1958). Assuming that phytoplankton can take up all the $\mathrm{N}$ coming from atmospheric deposition with no losses, and that there is no co-limitation by other nutrients (i.e. $\mathrm{P}$ and $\mathrm{Fe}$ ), total mean deposition flux of atmospheric TIN over the subarctic western North Pacific Ocean $\left(46 \mu \mathrm{mol} \mathrm{m} \mathrm{m}^{-2} \mathrm{~d}^{-1}\right)$ was found to be maximally responsible for the carbon uptake of $300 \mu \mathrm{mol} \mathrm{Cm}^{-2} \mathrm{~d}^{-1}$. Elskens et al. (2008) reported that the integrated new primary production in the upper part of the euphotic zone $(0-50 \mathrm{~m})$ at station $\mathrm{K} 2\left(47^{\circ} \mathrm{N}, 161^{\circ} \mathrm{E}\right)$ in the subarctic western North Pacific Ocean from 30 July 2005 to 18 August 2005 ranged from 67-119 mg C m${ }^{-2} \mathrm{~d}^{-1}$ (5.6-9.9 $\mathrm{mmol} \mathrm{C} \mathrm{m}^{-2} \mathrm{~d}^{-1}$ ). Wong et al. (2002) estimated that the annual new production from the surface (upper $50 \mathrm{~m}$ ) of the subarctic western North Pacific Ocean, which covers the sampling area of this study, to be $32.8-82.8 \mathrm{~g} \mathrm{C} \mathrm{m}^{-2} \mathrm{yr}^{-1}$. To facilitate evaluation, we have converted $\mathrm{g} \mathrm{C} \mathrm{m}^{-2} \mathrm{yr}^{-1}$ units for the annual new production 


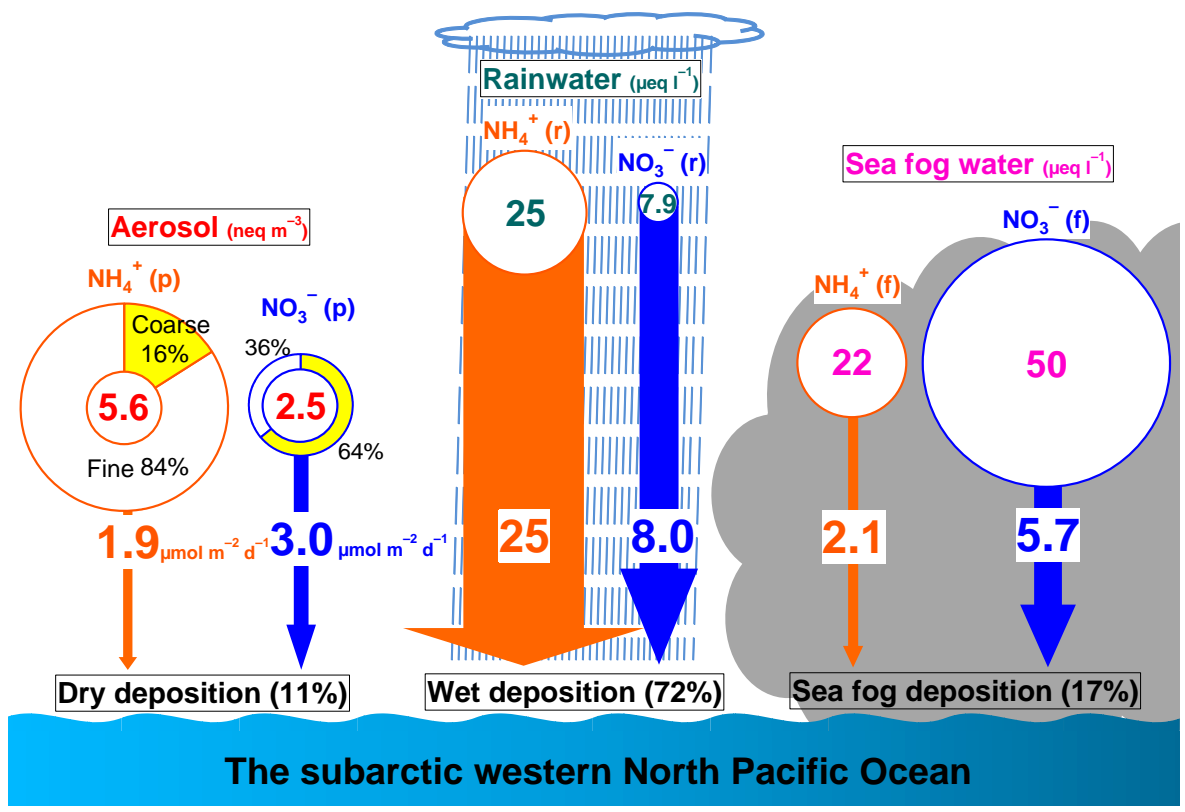

Fig. 10. Schematic diagram of atmospheric inorganic $\mathrm{N}$ input to the subarctic western North Pacific Ocean during 29 July-19 August 2008. The numbers in circles represent concentrations of $\mathrm{NH}_{4}^{+}$and $\mathrm{NO}_{3}^{-}$in aerosols (in neq $\mathrm{m}^{-3}$ ), rainwater (in $\mu$ eq $\mathrm{L}^{-1}$ ) and sea fog water (in $\mu$ eq $\left.\mathrm{L}^{-1}\right)$. The mean percentages of total (fine + coarse) aerosol concentrations in fine $(D<2.5 \mu \mathrm{m}$, white) and coarse $(D>2.5 \mu \mathrm{m}$, yellow) modes for $\mathrm{NH}_{4}^{+}$and $\mathrm{NO}_{3}^{-}$are shown in the circles for aerosol. The orange and blue arrows and numbers (in $\mu \mathrm{mol} \mathrm{m}-2 \mathrm{~d}^{-1}$ ) indicate $\mathrm{NH}_{4}^{+}$ (orange) and $\mathrm{NO}_{3}^{-}$(blue) fluxes via dry, wet, and sea fog deposition.

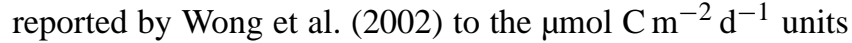
used in this study. Based on these estimates by Elskens et al. (2008) and Wong et al. (2002), the result of this study suggests that inorganic $\mathrm{N}$ deposited to the subarctic western North Pacific Ocean from the atmosphere can support 1.6$5.3 \%$ of the new primary production. Atmospheric inorganic $\mathrm{N}$ deposition, however, could be an important $\mathrm{N}$ source in the ocean where sporadic atmospheric $\mathrm{N}$ deposition events caused by the transport of the continental dust affect and the supply of deep nutrient-rich water is restricted by the stratification of the surface ocean that is enhanced by global warming.

\section{Conclusions}

The subarctic western North Pacific Ocean $\left(>40^{\circ} \mathrm{N}\right)$ has a high frequency of sea fog, with a maximum of $\sim 50 \%$ during the summertime period (June-August). The fog deposition is an important transfer process for atmospheric substances from the atmosphere to the biosphere. It is therefore suggested that sea fog may play a key role in supplying atmospheric nutrients to this region. Nevertheless, no study has been carried out over the subarctic western North Pacific Ocean to quantify sea fog deposition flux for atmospheric N. This is the first study to estimate atmospheric inorganic $\mathrm{N}$ fluxes via dry, wet, and sea fog deposition simultaneously over the subarctic western North
Pacific Ocean. The mean dry, wet, and sea fog deposition fluxes for TIN were estimated to be $4.9 \mu \mathrm{mol} \mathrm{m}^{-2} \mathrm{~d}^{-1}$, $33 \mu \mathrm{mol} \mathrm{m}{ }^{-2} \mathrm{~d}^{-1}$, and $7.8 \mu \mathrm{mol} \mathrm{m}{ }^{-2} \mathrm{~d}^{-1}$, respectively. Wet deposition delivered more atmospheric inorganic $\mathrm{N}$ to the subarctic western North Pacific Ocean than dry and sea fog deposition, contributing $\sim 72 \%$ to total deposition flux for TIN $\left(46 \mu \mathrm{mol} \mathrm{m}^{-2} \mathrm{~d}^{-1}\right)$, although the relative contributions are highly variable.

The mean contribution of sea fog deposition to total deposition flux for TIN was $\sim 17 \%$. Despite the relatively lower contribution of sea fog deposition, in some cases, atmospheric inorganic $\mathrm{N}$ input via sea fog deposition exceeded the combined dry and wet deposition fluxes. Thus, it is suggested that sea fog can result in substantial $\mathrm{N}$ deposition if the event persists long enough and has sufficient LWC (dense sea fog), and that ignoring sea fog deposition would lead to underestimate of the total influx of atmospheric inorganic $\mathrm{N}$ into the subarctic western North Pacific Ocean, especially in summer periods.

A schematic diagram of atmospheric inorganic $\mathrm{N}$ input to the subarctic western North Pacific Ocean via dry, wet, and sea fog deposition is shown in Fig. 10. In dry deposition, $\mathrm{NO}_{3}^{-}$was the dominant inorganic $\mathrm{N}$ species, accounting for $\sim 57 \%$. This reflects higher deposition velocity of $\mathrm{NO}_{3}^{-}$than that of $\mathrm{NH}_{4}^{+}$since $\mathrm{NO}_{3}^{-}$is largely associated with coarse mode particles in the marine atmosphere. In comparison, inorganic $\mathrm{N}$ supplied to surface waters by atmospheric wet 
deposition was predominantly by $\mathrm{NH}_{4}^{+}(72-89 \%$ of the wet deposition fluxes for TIN), suggesting that $\mathrm{NH}_{4}^{+}$is more important inorganic $\mathrm{N}$ species supplied by wet deposition over the subarctic western North Pacific Ocean. The contributions of $\mathrm{NH}_{4}^{+}$and $\mathrm{NO}_{3}^{-}$to the sea fog deposition flux for TIN were $\sim 39 \%$ and $\sim 61 \%$, respectively, indicating that sea fog scavenged more effectively not only coarse mode particles (e.g. sea-salt particles and $\mathrm{NaNO}_{3}$ ) that acted as $\mathrm{CN}$ of sea fog droplets, but also gaseous $\mathrm{HNO}_{3}$.

In this study, atmospheric inorganic $\mathrm{N}$ input via dry, wet, and sea fog deposition to the subarctic western North Pacific Ocean was estimated by simplified calculation (e.g. using assumption for sea fog water flux) during limited sampling period in the summer, but these results contributed to the understanding of atmospheric $\mathrm{N}$ cycle in open ocean environment. Further studies, however, are required to understand the biogeochemical cycles of $\mathrm{N}$ more clearly and should focus on long-term monitoring of atmospheric reactive $\mathrm{N}$ species, including organic $\mathrm{N}$, in the subarctic western North Pacific Ocean.

\section{Supplementary material related to this article is available online at: http://www.atmos-chem-phys.net/13/ 411/2013/acp-13-411-2013-supplement.pdf.}

Acknowledgements. We are grateful to the captains and crews of R/V Hakuho Maru for their enthusiastic assistance during Leg 1 of the KH-08-2. This study was supported by funds from the Grant-in-Aid for Scientific Research in Priority Areas "Western Pacific Air-Sea Interaction Study (W-PASS)" under Grant No. 18067005 from the Ministry of Education, Culture, Sports, Science and Technology (MEXT), Japan. This work was partly supported by the Sasakawa Scientific Research Grant from The Japan Science Society. This research is a contribution to the Surface Ocean Lower Atmosphere Study (SOLAS) Core Project of the International Geosphere-Biosphere Programme (IGBP). S. Yoon and S. Kim were supported by the Korea Meteorological Administration and Research and Development Program under Grant CATER 2012-3020.

Edited by: I. Trebs

\section{References}

Aikawa, M., Hiraki, T., Suzuki, M., Tamaki, M., and Kasahara, M.: Separate chemical characterizations of fog water, aerosol, and gas before, during, and after fog events near an industrialized area in Japan, Atmos. Environ., 41, 1950-1959, 2007.

Akimoto, H.: Global air quality and pollution, Science, 302, 17161719, doi:10.1126/science.1092666, 2003.

Ali, K., Momin, G. A., Tiwari, S., Safai, P. D., Chate, D. M., and Rao, P. S. P.: Fog and precipitation chemistry at Delhi, North India, Atmos. Environ., 38, 4215-4222, 2004.
Andreae, M. O. and Crutzen, P. J.: Atmospheric aerosols: biogeochemical sources and role in atmospheric chemistry, Science, 276, 1052-1058, doi:10.1126/science.276.5315.1052, 1997.

Andreae, M. O. and Merlet, P.: Emission of trace gases and aerosols from biomass burning, Global Biogeochem. Cy., 15, 955-966, doi:10.1029/2000GB001382, 2001.

Aneja, V. P., Roelle, P. A., Murray, G. C., Southerland, J., Erisman, J. W., Fowler, D., Asman, W. A. H., and Patni, N.: Atmospheric nitrogen compounds II: emissions, transport, transformation, deposition and assessment, Atmos. Environ., 35, 1903-1911, 2001.

Baker, A. R., Kelly, S. D., Biswas, K. F., Witt, M., and Jickells, T. D.: Atmospheric deposition of nutrients to the Atlantic Ocean, Geophys. Res. Lett., 30, 2296, doi:10.1029/2003GL018518, 2003.

Baker, A. R., Jickells, T. D., Biswas, K. F., Weston, K., and French, M.: Nutrient in atmospheric aerosol particles along the Atlantic Meridional Transect, Deep-Sea Res. Pt. II, 53, 1706-1719, 2006.

Baker, A. R., Weston, K., Kelly, S. D., Voss, M., Streu, P., and Cape, J. N.: Dry and wet deposition of nutrients from the tropical Atlantic atmosphere: Links to primary productivity and nitrogen fixation, Deep-Sea Res. Pt. I, 54, 1704-1720, 2007.

Baker, A. R., Lesworth, T., Adams, C., Jickells, T. D., and Ganzeveld, L.: Estimation of atmospheric nutrient inputs to the Atlantic Ocean from $50^{\circ} \mathrm{N}$ to $50^{\circ} \mathrm{S}$ based on large-scale field sampling: Fixed nitrogen and dry deposition of phosphorus, Global Biogeochem. Cy., 24, GB3006, doi:10.1029/2009GB003634, 2010.

Bardouki, H., Berresheim, H., Vrekoussis, M., Sciare, J., Kouvarakis, G., Oikonomou, K., Schneider, J., and Mihalopoulos, N.: Gaseous (DMS, MSA, $\mathrm{SO}_{2}, \mathrm{H}_{2} \mathrm{SO}_{4}$ and DMSO) and particulate (sulfate and methanesulfonate) sulfur species over the northeastern coast of Crete, Atmos. Chem. Phys., 3, 1871-1886, doi:10.5194/acp-3-1871-2003, 2003.

Burkard, R., Eugster, W., Wrzesinsky, T., and Klemm, O.: Vertical divergence of fogwater fluxes above a spruce forest, Atmos. Res., 64, 133-145, 2002.

Charlson, R. J., Lovelock, J. E., Andreae, M. O., and Warren, S. G.: Oceanic phytoplankton, atmospheric sulfur, cloud albedo and climate, Nature, 326, 655-661, 1987.

Chen, Y. and Siefert, R. L.: Seasonal and spatial distributions and dry deposition fluxes of atmospheric total and labile iron over the tropical and subtropical North Atlantic Ocean, J. Geophys. Res., 109, D09305, doi:10.1029/2003JD003958, 2004.

Chiapello, I., Bergametti, G., Chatenet, B., Bousquet, P., Dulac, F., and Soares, E. S.: Origins of African dust transported over the northeastern tropical Atlantic, J. Geophys. Res., 102, 1370113709, doi:10.1029/97JD00259, 1997.

Cho, Y. -K., Kim, M .-O., and Kim, B.-C.: Sea fog around the Korean Peninsula, J. Appl. Meteorol., 39, 2473-2479, 2000.

Collett Jr., J. L., Sherman, D. E., Moore, K. F., Hannigan, M. P., and Lee, T.: Aerosol particle processing and removal by fogs: observations in chemically heterogeneous central California radiation fogs, Water Air Soil Poll. Focus, 1, 303-312, 2001.

Collett Jr., J. L., Bator, A., Sherman, D. E., Moore, K. F., Hoag, K. J., Demoz, B. B., Rao, X., and Reilly, J. E.: The chemical composition of fogs and intercepted clouds in the United States, Atmos. Res., 64, 29-40, 2002.

Deboudt, K., Flament, P., and Bertho, M. L.: Cd, $\mathrm{Cu}, \mathrm{Pb}$ and $\mathrm{Zn}$ concentrations in atmospheric wet deposition at a coastal station 
in Western Europe, Water Air Soil Poll., 151, 335-359, 2004.

Dentener, F., Drevet, J., Lamarque, J. F., Bey, I., Eickhout, B., Fiore, A. M., Hauglustaine, D., Horowitz, L. W., Krol, M., Kulshrestha, U. C., Lawrence, M., Galy-Lacaux, C., Rast, S., Shindell, D., Stevenson, D., Van Noije, T., Atherton, C., Bell, N., Bergman, D., Butler, T., Cofala, J., Collins, B., Doherty, R., Ellingsen, K., Galloway, J., Gauss, M., Montanaro, V., Müller, J. F., Pitari, G., Rodriguez, J., Sanderson, M., Solmon, F., Strahan, S., Schultz, M., Sudo, K., Szopa, S., and Wild, O.: Nitrogen and sulfur deposition on regional and global scales: A multimodel evaluation, Global Biogeochem. Cy., 20, GB4003, doi:10.1029/2005GB002672, 2006.

Duce, R. A., Liss, P. S., Merrill, J. T., Atlas, E. L., Buat-Menard, P., Hicks, B. B., Miller, J. M., Prospero, J. M., Arimoto, R., Church, T. M., Ellis, W., Galloway, J. N., Hansen, L., Jickells, T. D., Knap, A. H., Reinhardt, K. H., Schneider, B., Soudine, A., Tokos, J. J., Tsunogai, S., Wollast, R., and Zhou, M.: The atmospheric input of trace species to the world ocean, Global Biogeochem. Cy., 5, 193-259, 1991.

Duce, R. A., LaRoche, J., Altieri, K., Arrigo, K. R., Baker, A. R., Capone, D. G., Cornell, S., Dentener, F., Galloway, J., Ganeshram, R. S., Geider, R. J., Jickells, T., Kuypers, M. M., Langlois, R., Liss, P. S., Liu, S. M., Middelburg, J. J., Moore, C. M., Nickovic, S., Oschlies, A., Pedersen, T., Prospero, J., Schlitzer, R., Seitzinger, S., Sorensen, L. L., Uematsu, M., Ulloa, O., Voss, M., Ward, B., and Zamora, L.: Impacts of Atmospheric Anthropogenic Nitrogen on the Open Ocean, Science, 320, 893 897, doi: 10.1126/science.1150369, 2008.

Eugster, W.: Fog research, Die Erde, 139, 1-10, 2008.

Elskens, M., Brion, N., Buesseler, K., Van Mooy, B. A. S., Boyd, P., Dehairs, F., Savoye, N., and Baeyens, W.: Primary, new and export production in the NW Pacific subarctic gyre during the vertigo K2 experiments, Deep-Sea Res. Pt. II, 55, 1594-1604, 2008.

Fahey, K. M., Pandis, S. N., Collett Jr., J. L., and Herckes, P.: The influence of size-dependent droplet composition on pollutant processing by fogs, Atmos. Environ., 39, 4561-4574, 2005.

Fu, G., Guo, J., Xie, S. -P., Duan, Y., and Zhang, M.: Analysis and high-resolution modeling of a dense sea fog event over the Yellow Sea, Atmos. Res., 81, 293-303, 2006.

Galloway, J. N., Dentener, F. J., Capone, D. G., Boyer, E. W., Howarth, R. W., Seitzinger, S. P., Asner, G. P., Cleveland, C. C., Green, P. A., Holland, E. A., Karl, D. M., Michaels, A. F., Porter, J. H., Townsend, A. R., and Voeroesmarty, C. J.: Nitrogen cycles: past, present, and future, Biogeochemistry, 70, 153-226, 2004.

Galloway, J. N., Townsend, A. R., Erisman, J. W., Bekunda, M., Cai, Z., Freney, J. R., Martinelli, L. A., Seitzinger, S. P., and Sutton, M. A.: Transformation of the Nitrogen Cycle: Recent Trends, Questions, and Potential Solutions, Science, 320, 889892, doi:10.1126/science.1136674, 2008.

Gao, Y., Arimoto, R., Zhou, M. Y., Merrill, J. T., and Duce, R. A.: Relationships between the dust concentrations over eastern Asia and the remote North Pacific, J. Geophys. Res., 97, 9867-9872, doi:10.1029/92JD00714, 1992.

Gilbert, P. M., Garside, C., Fuhrman, J. A., and Roman, M. R.: Time-dependent coupling of inorganic and organic nitrogen uptake and regeneration in the plume of the Chesapeake Bay estuary and its regulation by large heterotrophs, Limnol. Oceanogr., 36, 895-909, 1991.
Gioda, A., Reyes-Rodríguez, G. J., Santos-Figueroa, G., Collett Jr., J. L., Decesari, S., Ramos, M. d. C. K. V, Bezerra Netto, H. J. C., de Aquino Neto, F. R., and Mayol-Bracero, O. L.: Speciation of water-soluble inorganic, organic, and total nitrogen in a background marine environment: Cloud water, rainwater, and aerosol particles, J. Geophys. Res., 116, D05203, doi:10.1029/2010JD015010, 2011.

Gondwe, M., Krol, M., Gieskes, W., Klaassen, W., and de Baar, H.: The contribution of ocean-leaving DMS to the global atmospheric burdens of DMS, MSA, $\mathrm{SO}_{2}$, and $\mathrm{NSS} \mathrm{SO}_{4}^{=}$, Global Biogeochem. Cy., 17, 1056, doi:10.1029/2002GB001937, 2003.

Graedel, T. E. and Keene, W. C.: Tropospheric budget of reactive chlorine, Global Biogeochem. Cy., 9, 47-77, doi:10.1029/94GB03103, 1995.

Gultepe, I., Tardif, R., Michaelides, S. C., Cermak, J., Bott, A., Bendix, J., Müller, M. D., Pagowski, M., Hansen, B., Ellrod, G., Jacobs, W., Toth, G., and Cober, S. G.: Fog research: A review of past achievements and future perspectives, Pure Appl. Geophys., 164, 1121-1159, 2007.

Herckes, P., Chang, H., Lee, T., and Collett Jr., J. L.: Air pollution processing by radiation fogs, Water Air Soil Poll., 181, 65-75, 2007.

Jacob, D. J., Waldman, J. M., Munger, W., and Hoffmann, M. R.: A field investigation of physical and chemical mechanisms affecting pollutant concentrations in fog droplets, Tellus B, 36, 272285, 1984.

Jickells, T.: Atmospheric inputs of metals and nutrients to the oceans: their magnitude and effects, Mar. Chem., 48, 199-214, 1995.

Jickells, T.: The role of air-sea exchange in the marine nitrogen cycle, Biogeosciences, 3, 271-280, 2006,

http://www.biogeosciences.net/3/271/2006/.

Jickells, T. D., Kelly, S. D., Baker, A. R., Biswas, K., Dennis, P. F., Spokes, L. J., Witt, M., and Yeatman, S. G.: Isotopic evidence for a marine ammonia source, Geophys. Res. Lett., 30, 1374, doi:10.1029/2002GL016728, 2003

Jordan, C. E. and Talbot, R. W.: Direct atmospheric deposition of water-soluble nitrogen to the Gulf of Maine, Global Biogeochem. Cy., 14, 1315-1329, doi:10.1029/2000GB001266, 2000.

Jung, J., Furutani, H., and Uematsu, M.: Atmospheric inorganic nitrogen in marine aerosol and precipitation and its deposition to the North and South Pacific Oceans, J. Atmos. Chem., 68, 157$181,2011$.

Keene, W. C., Pszenny, A. A. P., Galloway, J. N., and Hawley, M. E.: Sea-salt corrections and interpretation of constituent ratios in marine precipitation, J. Geophys. Res., 91, 6647-6658, doi:10.1029/JD091iD06p06647, 1986.

Kim, T. -W., Lee, K., Najjar, R. G., Jeong, H.-D., and Jeong, H. J.: Increasing N Abundance in the Northwestern Pacific Ocean Due to Atmospheric Nitrogen Deposition, Science, 334, 505509, doi:10.1126/science.1206583, 2011.

Klemm, O. and Wrzesinsky, T.: Fog deposition fluxes of water and ions to a mountainous site in Central Europe, Tellus B, 59, 705714, 2007.

Klemm, O., Wrzesinsky, T., and Scheer, C.: Fog water flux at a canopy top: Direct measurement versus one-dimensional model, Atmos. Environ., 39, 5375-5386, 2005. 
Krishnamurthy, A., Moore, J. K., Mahowald, N., Luo, C., and Zender, C. S.: Impacts of atmospheric nutrient inputs on marine biogeochemistry, J. Geophys. Res., 115, G01006, doi:10.1029/2009JG001115, 2010.

Lange, C. A., Matschullat, J., Zimmermann, F., Sterzik, G., and Wienhaus, O.: Fog frequency and chemical composition of fog water - a relevant contribution to atmospheric deposition in the eastern Erzgebirge, Germany, Atmos. Environ., 37, 3731-3739, 2003

Larsen, J., Neal, C., Webley, P., Freymueller, J., Haney, M., McNutt, S., Schneider, D., Prejean, S., Schaefer, J., and Wessels, R.: Eruption of Alaska volcano breaks historic pattern, Eos Trans. AGU, 90, 173, doi:10.1029/2009EO200001, 2009.

Lewis, J. M., Koračin, D., and Redmond, K. T.: Sea fog research in the United Kingdom and United States: A historical essay including outlook, B. Am. Meteorol. Soc., 85, 395-408, 2004.

Li, P., Li, X., Yang, C., Wang, X., Chen, J., and Collett Jr., J. L.: Fog water chemistry in Shanghai, Atmos. Environ., 45, 4034-4041, 2011

Loo, B. W. and Cork, C. P.: Development of High Efficiency Virtual Impactors, Aerosol Sci. Technol., 9, 167-176, 1988.

Lovett, G. M., Reiners, W. A., and Olson, R. K.: Cloud Droplet Deposition in Subalpine Balsam Fir Forests: Hydrological and Chemical Inputs, Science, 218, 1303-1304, 1982.

Lu, C., Niu, S., Tang, L., Lv, J., Zhao, L., and Zhu, B.: Chemical composition of fog water in Nanjing area of China and its related fog microphysics, Atmos. Res., 97, 47-69, 2010.

Lu, Z. and Dzurisin, D.: Ground surface deformation patterns, magma supply, and magma storage at Okmok volcano, Alaska, from InSAR analysis: 2. Coeruptive deflation, July-August 2008, J. Geophys. Res., 115, B00B03, doi:10.1029/2009JB006970, 2010.

Matsumoto, K., Tominaga, S., and Igawa, M.: Measurements of atmospheric aerosols with diameters greater than $10 \mu \mathrm{m}$ and their contribution to fixed nitrogen deposition in coastal urban environment, Atmos. Environ., 45, 6433-6438, 2011.

Millet, M., Sanusi, A., and Wortham, H.: Chemical composition of fogwater in an urban area: Strasbourg (France), Environ. Pollut., 94, 345-354, 1996.

Minami, Y. and Ishizaka, Y.: Evaluation of chemical composition in fog water near the summit of a high mountain in Japan, Atmos. Environ., 30, 3363-3376, 1996.

Moore, K. F., Sherman, D. E., Reilly, J. E., and Collett Jr., J. L.: Drop size-dependent chemical composition in clouds and fogs. Part I. Observations, Atmos. Environ., 38, 1389-1402, 2004.

Nakamura, T., Matsumoto, K., and Uematsu, M.: Chemical characteristics of aerosols transported from Asia to the East China Sea: an evaluation of anthropogenic combined nitrogen deposition in autumn, Atmos. Environ., 39, 1749-1758, 2005.

Paerl, H. W.: Coastal eutrophication and harmful algal blooms: importance of atmospheric deposition and groundwater as "new" nitrogen and other nutrient sources, Limnol. Oceanogr., 42, 1154-1165, 1997.

Pandis, S. N. and Seinfeld, J. H.: The smog-fog-smog cycle and acid deposition, J. Geophys. Res., 95, 18489-18500, doi:10.1029/JD095iD11p18489, 1990.

Prospero, J. M., Barrett, K., Church, T., Dentener, F., Duce, R. A., Galloway, J. N., Levy II, H., , Moody, J., and Quinn, P.: Atmospheric deposition of nutrients to the North Atlantic basin, Bio- geochemistry, 35, 27-73, 1996.

Quinn, P. K., Charlson, R. J., and Zoller, W. H.: Ammonia, the dominant base in the remote marine troposphere: a review, Tellus B, 39B, 413-425, 1987.

Raja, S., Raghunathan, R., Yu, X. -Y., Lee, T., Chen, J., Kommalapati, R. R., Murugesan, K., Shen, X., Yuan, Q., Valsaraj, K. T., and Collett Jr., J. L.: Fog chemistry in the Texas-Louisiana Gulf Coast corridor, Atmos. Environ., 42, 2048-2061, 2008.

Redfield, A. C.: The biological control of chemical factors in the environment, Am. Sci., 46, 205-221, 1958.

Sasakawa, M. and Uematsu, M.: Chemical composition of aerosol, sea fog, and rainwater in the marine boundary layer of the northwestern North Pacific and its marginal seas, J. Geophys. Res., 107, 4783, doi:10.1029/2001JD001004, 2002.

Sasakawa, M. and Uematsu, M.: Relative contribution of chemical composition to acidification of sea fog (stratus) over the northern North Pacific and its marginal seas, Atmos. Environ., 39, 1357 1362, 2005.

Sasakawa, M., Ooki, A., and Uematsu, M.: Aerosol size distribution during sea fog and its scavenge process of chemical substances over the northwestern North Pacific, J. Geophys. Res., 108, 4120, doi:10.1029/2002JD002329, 2003.

Schmale, J., Schneider, J., Jurkat, T., Voigt, C., Kalesse, H., Rautenhaus, M., Lichtenstern, M., Schlager, H., Ancellet, G., Arnold, F., Gerding, M., Mattis, I., Wendisch, M., and Borrmann, S.: Aerosol layers from the 2008 eruptions of Mount Okmok and Mount Kasatochi: In situ upper troposphere and lower stratosphere measurements of sulfate and organics over Europe, J. Geophys. Res., 115, D00L07, doi:10.1029/2009JD013628, 2010.

Spiegel, J. K., Zieger, P., Bukowiecki, N., Hammer, E., Weingartner, E., and Eugster, W.: Evaluating the capabilities and uncertainties of droplet measurements for the fog droplet spectrometer (FM-100), Atmos. Meas. Tech., 5, 2237-2260, doi:10.5194/amt5-2237-2012, 2012

Spokes, L. J., Yeatman, S. G., Cornell, S. E., and Jickells, T. D.: Nitrogen deposition to the eastern Atlantic Ocean. The importance of south-easterly flow, Tellus B, 52, 37-49, 2000.

Thalmann, E., Burkard, R., Wrzesinsky, T., Eugster, W., and Klemm, O.: Ion fluxes from fog and rain to an agricultural and a forest ecosystem in Europe, Atmos. Res., 64, 147-158, 2002.

Tokinaga, H. and Xie, S. -P.: Ocean tidal cooling effect on summer sea fog over the Okhotsk Sea, J. Geophys. Res., 114, D14102, doi:10.1029/2008JD011477, 2009.

Uematsu, M., Duce, R. A., Prospero, J. M., Chen, L., Merrill, J. T., and McDonald, R. L.: Transport of mineral aerosol from Asia over the North Pacific Ocean, J. Geophys. Res., 88, 5343-5352, doi:10.1029/JC088iC09p05343, 1983.

Uematsu, M., Hattori, H., Nakamura, T., Narita, Y., Jung, J., Matsumoto, K., Nakaguchi, Y., and Dileep Kumar, M.: Atmospheric transport and deposition of anthropogenic substances from the Asia to the East China Sea, Mar. Chem., 120, 108-115, 2010.

Uno, I., Uematsu, M., Hara, Y., He, Y. J., Ohara, T., Mori, A., Kamaya, T., Murano, K., Sadanaga, Y., and Bandow, H.: Numerical study of the atmospheric input of anthropogenic total nitrate to the marginal seas in the western North Pacific region, Geophys. Res. Lett., 34, L17817, doi:10.1029/2007GL030338, 2007.

Wang, B.-H.: Distributions and variations of sea fog in the world, in: Sea Fog, China Ocean Press, Beijing, 51-90, 1985. 
Wong, C. S., Waser, N. A. D., Nojiri, Y., Whitney, F. A., Page, J. S., and Zeng, J.: Seasonal cycles of nutrients and dissolved inorganic carbon at high and mid latitudes in the North Pacific Ocean during the Skaugran cruises: determination of new production and nutrient uptake ratios, Deep-Sea Res. Pt. II, 49, 5317-5338, 2002.

Xie, P. and Arkin, P. A.: Global precipitation: A 17-year monthly analysis based on gauge observations, satellite estimates, and numerical model outputs, B. Am. Meteorol. Soc., 78, 2539-2558, 1997.
Zhang, Q. and Anastasio, C.: Chemistry of fog waters in California's Central Valley - Part 3. Concentrations and speciation of organic and inorganic nitrogen, Atmos. Environ., 35, 5629-5643, 2001.

Zhang, Y., Yu, Q., Ma, W., and Chen, L.: Atmospheric deposition of inorganic nitrogen to the eastern China seas and its implications to marine biogeochemistry, J. Geophys. Res., 115, D00K10, doi:10.1029/2009JD012814, 2010. 